\title{
Access site complications of postcardiotomy extracorporeal life support
}

Anne-Kristin Schaefer, MD, ${ }^{\mathrm{a}}$ Klaus Distelmaier, MD, ${ }^{\mathrm{b}}$ Julia Riebandt, MD, ${ }^{\mathrm{a}}$ Georg Goliasch, MD, Martin H. Bernardi, MD, ${ }^{\mathrm{c}}$ Daniel Zimpfer, MD, ${ }^{\mathrm{a}}$ Günther Laufer, MD, ${ }^{\mathrm{a}}$ and Dominik Wiedemann, $\mathrm{MD}^{\mathrm{a}}$

\section{ABSTRACT}

Objective: To assess the influence of primary arterial access in patients receiving peripheral postcardiotomy extracorporeal life support on associated complications and outcome.

Methods: Of 573 consecutive patients requiring PC-ECLS between 2000 and 2019 at a single center, 436 were included in a retrospective analysis and grouped according to primary arterial extracorporeal life support access site. Survival and rate of access-site-related complications with special emphasis on fatal/disabling stroke were compared.

Results: The axillary artery was cannulated in 250 patients (57.3\%), whereas the femoral artery was used as primary arterial access in 186 patients (42.6\%). There was no significant difference in 30-day (axillary: $62 \%$; femoral: $64.7 \%$; $P=.561$ ) and 1-year survival (axillary: $42.5 \%$; femoral: $44.8 \% ; P=.657$ ). Cerebral computed tomography-confirmed stroke with a modified ranking scale $\geq 4$ was significantly more frequent in the axillary group (axillary: $n=28,11.2 \%$; femoral: $n=4,2.2 \%$; $P=.0003)$. Stroke localization was right hemispheric $(n=20 ; 62.5 \%)$; left hemispheric $(n=5 ; 15.6 \%)$, bilateral $(n=5 ; 15.6 \%)$, or infratentorial $(n=2 ; 6.25 \%)$. Although no difference in major cannulation site bleeding was observed, cannulation site change for bleeding was more frequent in the axillary group (axillary: $\mathrm{n}=13 ; 5.2 \%$; femoral: $\mathrm{n}=2 ; 1.1 \% ; P=.03$ ). Clinically apparent $\operatorname{limb}$ ischemia was significantly more frequent in the femoral group (axillary: $\mathrm{n}=12,4.8 \%$; femoral: $\mathrm{n}=31,16.7 \% ; \mathrm{P}<.0001)$.

Conclusions: Although survival did not differ, surgeons should be aware of accesssite-specific complications when choosing peripheral PC-ECLS access. Although lower rates of limb ischemia and the advantage of antegrade flow seem beneficial for axillary cannulation, the high incidence of right hemispheric strokes in axillary artery cannulation should be considered. (J Thorac Cardiovasc Surg 2022;164:1546-58)

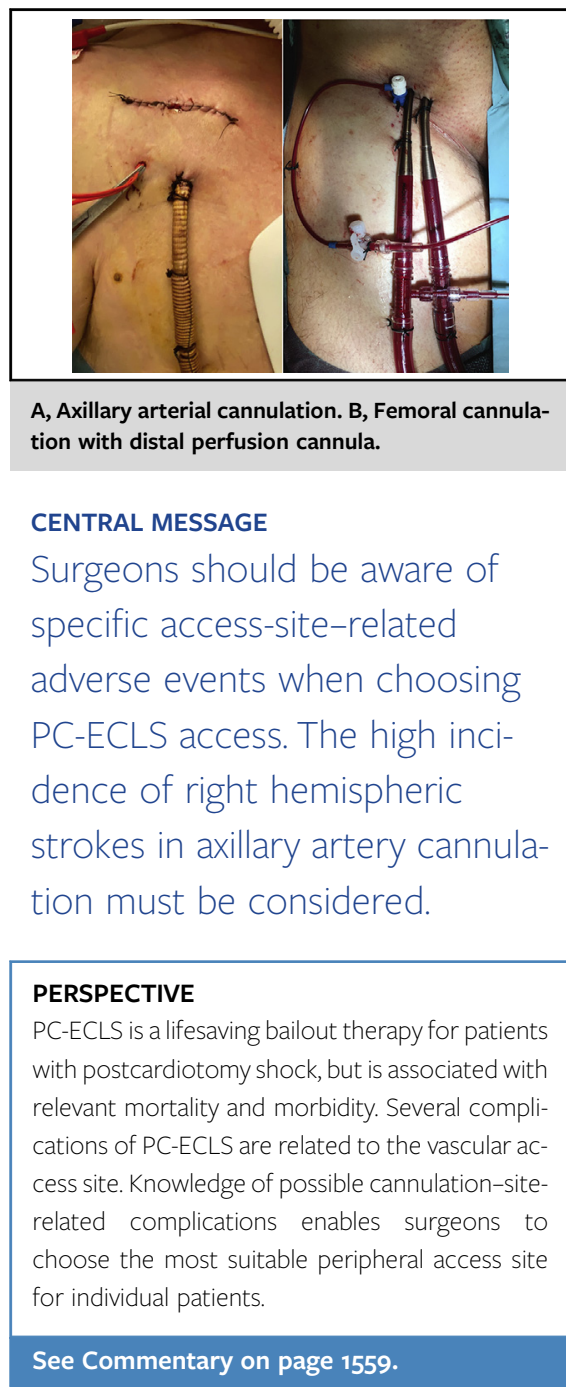

Complexity of cardiac surgical procedures has risen during the past decades. Along with increasing age and morbidity of the patient population, the number of patients requiring postcardiotomy temporary extracorporeal life support (PC-ECLS) steadily increases. ${ }^{1-3}$ Indications for

From the Departments of ${ }^{\mathrm{a} C a r d i a c}$ Surgery, ${ }^{\mathrm{b}}$ Internal Medicine II, and ${ }^{\mathrm{c}}$ Cardiac Thoracic Vascular Anaesthesia and Intensive Care Medicine, Medical University of Vienna, Vienna, Austria.

Read at the 101st Annual Meeting of The American Association for Thoracic Surgery: A Virtual Learning Experience, April 30-May 2, 2021.

Received for publication April 26, 2021; revisions received Aug 29, 2021; accepted for publication Sept 10, 2021; available ahead of print Nov 25, 2021.
PC-ECLS are mainly inability to separate from cardiopulmonary bypass, or cardiopulmonary failure of various etiologies during the early postoperative period. Although the primary therapeutic goal is bridging to myocardial recovery and weaning from the device, bridging to durable

\footnotetext{
Address for reprints: Dominik Wiedemann, MD, Department of Cardiac Surgery, Medical University of Vienna, Waehringer Guertel 18-20, 1090 Vienna, Austria. (E-mail: dominik.wiedemann@meduniwien.ac.at). 0022-5223

Copyright (c) 2021 The Authors. Published by Elsevier Inc. on behalf of The American Association for Thoracic Surgery. This is an open access article under the CC BY license (http://creativecommons.org/licenses/by/4.0/). https://doi.org/10.1016/j.jtcvs.2021.09.074
} 


\section{Abbreviations and Acronyms \\ aPTT = activated partial thromboplastin time \\ $\mathrm{CCT}=$ cerebral computed tomography \\ $\mathrm{CPB}=$ cardiopulmonary bypass \\ $\mathrm{CPR}=$ cardiopulmonary resuscitation \\ DPC = distal perfusion cannula \\ HTX $=$ heart transplantation \\ LCOS = low cardiac output syndrome \\ MCS = mechanical circulatory support \\ MRS = modified ranking scale \\ PC-ECLS $=$ postcardiotomy extracorporeal life support \\ $\mathrm{VAD}=$ ventricular assist device \\ Xclamp $=$ aortic crossclamp time}

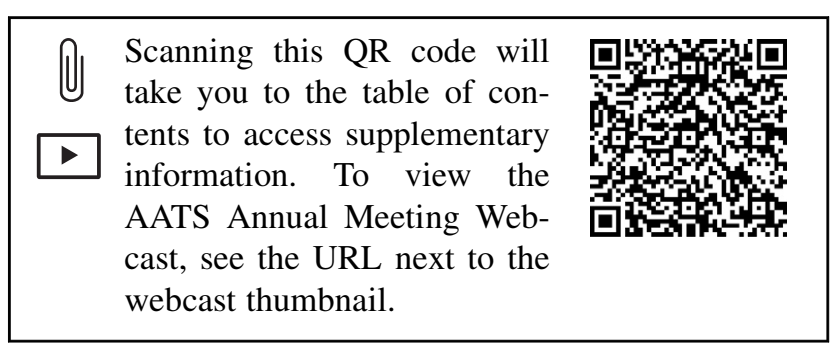

mechanical circulatory support (MCS) or heart transplantation is an option for eligible patients when ECLS weaning is unlikely or unsuccessful. ${ }^{4,5}$

Despite technical and medical advances, the mortality of PC-ECLS patients remains high with reported in-hospital survival rates ranging from $25 \%$ to $46 \% .^{6-11}$ Furthermore, PC-ECLS is associated with a number of potentially devastating complications that may arise during therapy and limit outcome, some of which are directly related to the site of cannulation, including limb ischemia and cannulation site bleeding. Cerebrovascular events are another frequent and often fatal complication. ${ }^{12,13}$

With growing experience, peripheral vessel access has become the recommended strategy for PC-ECLS. ${ }^{4}$ Main advantages over central cannulation are the facilitated sternal closure, the lower risk for infection and mediastinal bleeding, as well as the easier intensive care unit handling and ECLS explantation. A recent meta-analysis also reported higher mortality in patients with central cannulation. ${ }^{14}$

Evidence on which peripheral access site is preferable is still scarce. Different peripheral arterial access sites have variable flow properties related to the location of the arterial cannula in the bloodstream. Cannulation of the axillary artery allows for predominantly antegrade body perfusion and proximal shift of the watershed, therefore preventing differential hypoxemia in patients with compromised pulmonary function. ${ }^{15-18}$ Another obvious advantage of axillary cannulation is the uncompromised leg perfusion, avoiding leg ischemia and related problems. For the stated reasons, indirect axillary artery cannulation via side graft has evolved to be the preferred access site for elective implantation at our center in recent years, whereas the femoral artery remains the access of choice in cases where rapid ECLS initiation is required.

Despite all advantages, cerebral blood flow properties are more likely to be influenced in axillary artery cannulation because of the anatomic proximity of the cannulation site, which might represent a potential source of cerebral embolism. A possible relation of vascular ECLS access site and cerebrovascular adverse events is conceivable, but yet unclear. Furthermore, indirect axillary cannulation via an anastomosed side graft poses a risk of bleeding from the cannulation site.

The aim of this study was to compare axillary and femoral artery cannulation in terms of outcome and the incidence of cannulation-site-related and cerebrovascular adverse events, as well as further assessment of the location of stroke in these patients.

\section{METHODS \\ Study Population}

The data of all patients undergoing PC-ECLS at the Department of Cardiac Surgery, Medical University of Vienna, were collected within an institutional database approved by the local ethics committee of the Medical University of Vienna (institutional review board No. 1086/2019), in compliance with the Declaration of Helsinki. Informed consent was waived due to the retrospective study design.

All consecutive patients who received PC-ECLS from 2000 to 2019 $(\mathrm{N}=573)$ at the Department of Cardiac Surgery at the Medical University of Vienna were screened for the inclusion and exclusion criteria stated below.

\section{Inclusion Criteria}

Patients aged 18 years or older who received ECLS after cardiopulmonary bypass (CPB) either intraoperatively or within 72 hours postoperatively for postcardiotomy low cardiac output syndrome (LCOS), cardiopulmonary resuscitation, or hemodynamic/respiratory instability of other etiologies necessitating initiation of ECLS.

There is no defined age cutoff for PC-ECLS at our institution, and whenever a patient is determined to be a candidate for cardiac surgery, advanced age is not regarded a contraindication for ECLS if required to treat postcardiotomy shock. However, older patients are less likely to be eligible candidates for durable MCS or heart transplantation (HTX) and therapy may be withdrawn in the case the patient cannot be weaned from ECLS. In this case, a weaning attempt is made and ECLS explanted. HTX age cutoff is 70 years in our center, and although there is no absolute age cutoff for durable MCS, we are more restrictive with durable MCS implantation in patients aged 75 years or older. In cases when we anticipate that the patient will not be weanable from ECLS because of an underlying structural cardiac defect, we are more restrictive with ECLS implementation when the patient is no candidate for ventricular assist device (VAD)/HTX.

\section{Exclusion Criteria}

Patients were excluded in the case that 1 or more of the following criteria was met (Figure 1): 


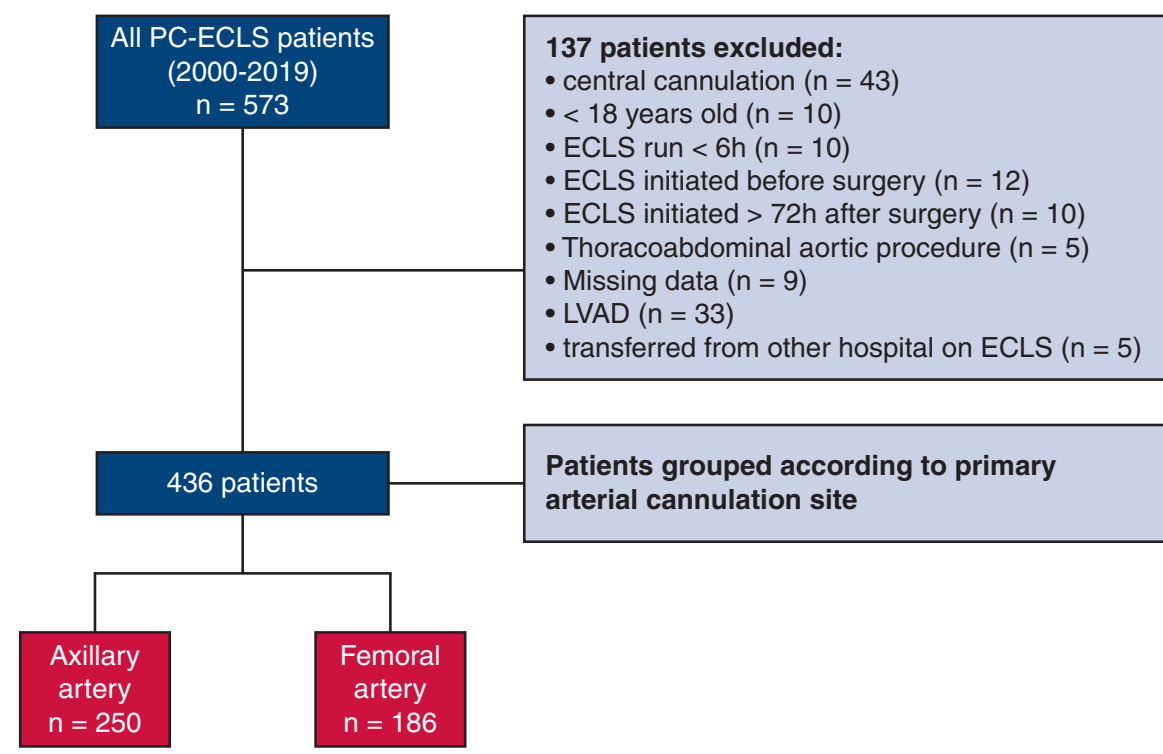

FIGURE 1. Study flowchart. Five hundred seventy-three consecutive patients undergoing postcardiotomy extracorporeal life support (PC-ECLS) from 2000 to 2019 were screened for inclusion and exclusion criteria. Four hundred thirty-six patients were included in a retrospective analysis and grouped by primary arterial cannulation site (axillary artery $\mathrm{n}=250$ or femoral artery $\mathrm{n}=186$ ). LVAD, Left ventricular assist device.

- Central ECLS cannulation,

- ECLS already installed before surgery/before CPB,

- Patients who received ECLS for temporary right ventricular support at the time of left VAD implantation,

- Patients undergoing thoracoabdominal aortic surgery,

- Patients with a duration of ECLS $<6$ hours,

- ECLS implanted $>72$ hours after the end of surgery,

- Patients younger than age 18 years,

- Missing data, and/or

- Patients transferred on ECLS from another hospital.

Patients who received ECLS $>72$ hours after surgery were excluded to exclude patients with delayed complications of surgery that occurred after the patient has already been transferred to the regular ward, such as unexpected, brisk bleeding leading to tamponade and cardiopulmonary resuscitation and ECLS implantation under emergency conditions on a normal ward. These patients have unfavorable prognosis due to the unexpected and sudden deterioration in a less-controlled environment (ward vs intensive care unit), and we therefore believe these patients are not comparable to patients receiving ECLS during or shortly after cardiac surgery. However, because the majority of patients who required PC-ECLS at our center received ECLS intraoperatively or within 72 hours after surgery, using a cutoff of 72 hours, only a very low number of patients had to be excluded.

\section{Clinical Definitions and End Points}

Indication for ECLS implantation was:

- Inability to separate from CPB because of LCOS, respiratory or metabolic instability with signs of anaerobic metabolism upon CPB weaning despite optimized supportive measures (ie, adequate vasopressor and inotropic support and fluid status), or

- Postoperative LCOS or hemodynamic or respiratory instability of any cause not amenable to conservative measures and requiring the implantation of ECLS, or postoperative cardiac arrest.

All-cause 30-day mortality was set as the primary end point. Incidence of cerebrovascular and access-site-related complications (stroke with modified ranking scale [MRS] $\geq 4$, cannulation site bleeding requiring surgical revision and/or change of cannulation site, extremity ischemia and wound healing disorders), as well as all-cause long-term mortality were secondary end points.

\section{Peripheral ECLS Cannulation}

For axillary cannulation, the axillary artery is exposed and proximal and distal control is obtained. In the case that the patient is still on CPB at the time of implantation, an activated clotting time of $>400$ seconds is maintained. In the case that ECLS implantation is performed in a patient who is not on CPB, $5000 \mathrm{IU}$ unfractionated heparin is administered before a side-biting clamp is applied to the vessel. An 8-mm polyethylene terephthalate graft is then anastomosed end-to-side. A $19 \mathrm{~F}$ or $21 \mathrm{~F}$ arterial cannula is inserted via the graft with the cannula tip placed 0.5 to $1 \mathrm{~cm}$ proximal to the anastomosis and secured to the graft with silk ligatures. A silicone vessel-loop is placed distally around the axillary artery, and a biradial invasive blood pressure monitoring is installed to enable regulation of the perfusion of the right arm. A venous drainage cannula is percutaneously inserted via the femoral vein.

For femoral cannulation, the right or left common femoral artery is either percutaneously cannulated using the Seldinger technique or surgically exposed. A distal perfusion cannula (DPC) is used depending on vessel diameter and surgeon's preference. A representative video of axillary arterial cannulation is provided (Video 1).

\section{Patient Management on ECLS}

Anticoagulation on ECLS was performed with continuous intravenous administration of 7.5 to $20 \mathrm{IU} / \mathrm{kg} / \mathrm{h}$ unfractionated heparin and monitored by activated partial thromboplastin time (aPTT) with a target therapeutic aPTT range of 1.5 to $2.5 \times$ baseline. In case of confirmed or suspected heparin induced thrombocytopenia, argatroban was used instead of heparin with the same target aPTT. Anticoagulation was adapted or discontinued in case of severe mediastinal bleeding. ${ }^{19}$

Patients who receive ECLS during surgery are transferred to an intensive care unit specialized on the postoperative care of patients after cardiac surgery. The decision to initiate ECLS, irrespective of intraoperatively or postoperatively, is made with a multidisciplinary team approach involving anesthesiologists, intensivists as well as the surgeon who performed the surgery. 


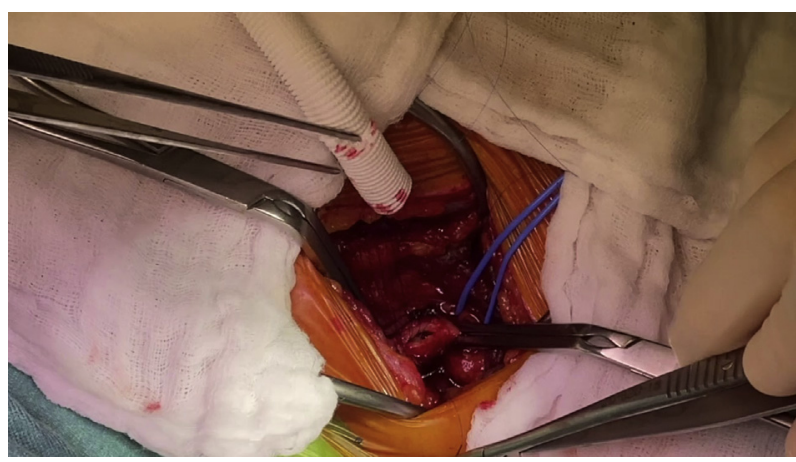

VIDEO 1. Representative video of axillary arterial cannulation for postcardiotomy extracorporeal life support (PC-ECLS) using an 8-mm polyethylene terephthalate side graft. Video available at: https://www.jtcvs.org/ article/S0022-5223(21)01659-7/fulltext.

Although a standardized weaning protocol has been developed at our institution within recent years, this was not available for the majority of the study period. In case of absent recovery, patients are evaluated for durable left ventricular assist device/HTX or ECLS is withdrawn after repeatedly unsuccessful ECLS weaning attempts if the patient is not eligible for left VAD/HTX, after thorough ethical consideration, interdisciplinary discussion of the case and involvement of the patient's family.

\section{Follow-up}

Survival data were retrieved from federal statistics (Statistics Austria, Vienna, Austria) and patient records. Hospital records were used to characterize intra- and postoperative course, as well as incidence of cerebral and access site related adverse events.

Cerebral computed tomography (CCT) images were acquired during clinical routine in case of clinical suspicion of stroke and were retrospectively assessed for stroke location. Stroke severity was graded by clinical presentation and neurological assessment using MRS at the time of hospital discharge. Stroke with MRS $\geq 2$ at the time of hospital discharge was classified as a disabling stroke according to the proposed definition for standardized neurological end points for cardiovascular clinical trials published by The Neurologic Academic Research Consortium, ${ }^{20}$ together with evidence of ischemic or hemorrhagic stroke on CCT. Additionally, the rate of patients with MRS $\geq 4$ is reported.

\section{Statistical Analysis}

All statistical analyses were performed using Prism for Mac OS version 8.1.2 (GraphPad Software Inc, San Diego, Calif). Data are presented as median and interquartile range (IQR) for continuous variables, and absolute and relative frequencies for categorical variables. Survival was estimated using Kaplan-Meier curves and group comparisons of survival depending on primary arterial cannulation site performed by log rank test. For group comparisons of baseline characteristics, procedural variables, and adverse event rates, Fisher exact test was used for categorical variables, and MannWhitney $U$ test for continuous variables. To identify risk factors of fatal/ disabling stroke, a multivariable binary logistic regression model was used, including clinically relevant and statistically significant parameters from the bivariate analysis. Two-tailed $P<.05$ was considered statistically significant.

\section{RESULTS}

\section{Patients}

Between February 2000 and December 2019 a total of 573 patients required PC-ECLS at our center. After application of inclusion and exclusion criteria listed in Figure 1,
436 patients with primary peripheral ECLS cannulation were included in the analysis and divided into groups according to the primary arterial access site (axillary artery, $\mathrm{n}=250$ or femoral artery, $\mathrm{n}=186$ ).

\section{Baseline Characteristics}

Patients with primary axillary arterial cannulation were older, had a higher European System for Cardiac Operative Risk Evaluation II score (EuroSCORE II), higher prevalence of coronary artery disease, lower preoperative bilirubin level, aspartate aminotransferase level, and hemoglobin level, and a higher prevalence of peripheral arterial disease. There was no significant difference in the other studied baseline variables. Baseline characteristics are presented in Table 1.

\section{Peripheral Arterial ECLS Access}

Of 436 patients with peripheral ECLS cannulation, the axillary artery was cannulated in 250 patients $(57.3 \%)$, whereas the femoral artery was used as primary access site in 186 patients $(42.6 \%)$. In case of axillary cannulation, the right axillary artery was used in the majority of patients $(\mathrm{n}=242 ; 96.8 \%)$, whereas the left axillary artery was used infrequently $(\mathrm{n}=8 ; 3.2 \%)$.

\section{Operative Data and ECLS Indication}

Procedure duration, CPB and aortic crossclamp (Xclamp) time were significantly longer in the axillary group, and the rate of surgery for type-A aortic dissection was higher in the axillary group. Periprocedural data are shown in Table 2. The rate of patients requiring cardiopulmonary resuscitation (CPR) before ECLS initiation, as well as the number of patients implanted under ongoing CPR was significantly higher in the group with primary femoral cannulation.

Indication for ECLS was intraoperative failure to separate from CPB (73.6\%), or postoperative LCOS or hemodynamic/metabolic instability/cardiopulmonary resuscitation within 72 hours from surgery $(26.4 \%)$. The duration of ECLS was significantly longer in the axillary group (4.6 days [IQR, 2.9-7.1 days] vs 4 days [IQR, 2.56.1 days]; $P=.044$ ) (Table 3 ).

\section{Survival}

There was no significant difference in survival after 30 days (axillary: $62 \%$; femoral: $64.7 \% ; P=.561$ ) and 1 year (axillary: $42.5 \%$; femoral: $44.8 \% ; P=.657$ ) after ECLS initiation between patients with primary arterial ECLS cannulation of the axillary artery and femoral artery. There also was no difference in overall survival $(P=.766)$ (Figure 2).

Older age, lower preoperative glomerular filtration rate, longer duration of ECLS support, and performed procedure 
TABLE 1. Baseline characteristics of the study cohort grouped by primary arterial extracorporeal life support (ECLS) access site

\begin{tabular}{|c|c|c|c|c|}
\hline Characteristic & $\begin{array}{l}\text { Total study population } \\
\qquad(\mathrm{N}=\mathbf{4 3 6})\end{array}$ & Indirect axillary $(n=250)$ & Femoral $(n=186)$ & $P$ value \\
\hline Age $(y)$ & $67.0(57.2-73.8)$ & $68.7(58.3-75.0)$ & $65(55.8-71.5)$ & $.0051^{*}$ \\
\hline Male sex & $287(65.8)$ & $163(65.2)$ & $124(66.7)$ & .7605 \\
\hline EuroSCORE II & $14.2(5.9-30.9)$ & $15.0(6.8-31.7)$ & $11.0(3.9-28.1)$ & $.0034 *$ \\
\hline BMI & $26.8(24.0-30.0)$ & $26.8(23.5-29.9)$ & $26.7(24.3-30.1)$ & .5451 \\
\hline Hypertension & 312 (71.6) & $186(73.6)$ & $126(67.7)$ & .1341 \\
\hline Hypercholesterolemia & $236(54.1)$ & $142(56.8)$ & $94(50.5)$ & .2074 \\
\hline $\begin{array}{l}\text { Insulin-dependent diabetes } \\
\text { mellitus }\end{array}$ & $32(7.3)$ & $21(8.4)$ & $11(5.9)$ & .3585 \\
\hline Coronary artery disease & $243(55.7)$ & $155(62)$ & $88(47.3)$ & $.0025^{*}$ \\
\hline $\begin{array}{l}\text { Left ventricular ejection fraction } \\
<15 \% \text { or previous VAD }\end{array}$ & $78(17.9)$ & $40(16)$ & $38(20.4)$ & .2564 \\
\hline \multicolumn{5}{|l|}{ LVEF } \\
\hline $16 \%-30 \%$ & $88(20.2)$ & $48(19.2)$ & $40(21.5)$ & .6296 \\
\hline $31 \%-50 \%$ & $105(24.1)$ & $66(26.4)$ & $39(21)$ & .2134 \\
\hline$\geq 51 \%$ & $147(33.7)$ & $86(34.4)$ & $61(32.8)$ & .7592 \\
\hline Creatinine (mg/dL) & $1.3(1-1.8)$ & $1.3(1-1.7)$ & $1.3(1.1-1.8)$ & .0821 \\
\hline $\begin{array}{l}\text { Estimated glomerular filtration } \\
\quad \text { rate }\left(\mathrm{mL} / \mathrm{min} / 1.73 \mathrm{~m}^{2}\right)\end{array}$ & $57.4(39.4-79)$ & $57.4(39.3-75.9)$ & $56.7(40.3-82.3)$ & .9479 \\
\hline Blood urea nitrogen $(\mathrm{mg} / \mathrm{dL})$ & $24(17-36.8)$ & $23(16.4-34)$ & $25(18.6-40.8)$ & .0644 \\
\hline Total bilirubin (mg/dL) & $1(0.6-1.2)$ & $1(0.5-1.2)$ & $1(1-1.1)$ & $.0257^{*}$ \\
\hline ASAT (U/L) & $30(22-52.3)$ & $28(21-49)$ & $35(23.5-60.5)$ & $.0068^{*}$ \\
\hline ALAT (U/L) & $26(18-43)$ & $26(18-40)$ & $28(18-48.5)$ & .2798 \\
\hline Gamma-GT (U/L) & $59(33-104)$ & $59.5(32.8-98.3)$ & $54(33-116.5)$ & .8644 \\
\hline Hemoglobin (mg/dL) & $12(10.3-13.9)$ & $11.9(10.2-13.3)$ & $12.6(11-14)$ & $.0139 *$ \\
\hline C-reactive protein (mg/dL) & $1(0.1-4)$ & $1(0.2-4)$ & $1(0.1-3.6)$ & .9597 \\
\hline Peripheral arterial disease & $61(14)$ & $45(18)$ & $16(8.6)$ & $.0052^{*}$ \\
\hline Cerebrovascular disease & $62(14.2)$ & $42(16.8)$ & $20(10.8)$ & .0956 \\
\hline Previous stroke/TIA & $74(17)$ & $46(18.4)$ & $28(15.1)$ & .3701 \\
\hline Previous cardiac surgery & 139 (31.9) & $81(32.4)$ & $58(31.2)$ & .8356 \\
\hline Previous VAD & $21(4.8)$ & $10(4)$ & $11(5.9)$ & .3741 \\
\hline Previous HTX & $1(0.23)$ & $1(0.4)$ & $0(0)$ & $>.9999$ \\
\hline Active endocarditis & $46(10.6)$ & $31(12.4)$ & $15(8.1)$ & .1586 \\
\hline
\end{tabular}

Values are presented as median (interquartile range) for continuous variables and absolute numbers (\%) categorical variables. EuroSCORE, European System for Cardiac Operative Risk Evaluation score $B M I$, body mass index; VAD, ventricular assist device; $L V E F$, left ventricular ejection fraction; $A S A T$, aspartate aminotransferase; $A L A T$, alanine aminotransferase; gamma-GT, gamma-glutamyl transferase; $T I A$, transient ischemic attack; $H T X$, heart transplantation. *Significantly different.

were significantly associated with mortality in a Cox proportional hazards model for mortality (Tables E1 and E2).

\section{Cerebral and Access-Site-Related Adverse Events}

Incidence of CCT-confirmed stroke with an MRS $\geq 4$ was significantly higher in the axillary group (axillary: $\mathrm{n}=28$, $11.2 \%$ vs femoral: $\mathrm{n}=4,2.2 \% ; P=.0003$ ). Although there was no significant difference in major cannulation site bleeding requiring surgical revision, change of cannulation site because of bleeding was significantly more frequent in the axillary group (axillary: $\mathrm{n}=13 ; 5.2 \%$ vs femoral: $\mathrm{n}=2$; $1.1 \% ; P=.03)$.

Clinically apparent limb ischemia (axillary: $\mathrm{n}=12,4.8 \%$; femoral: $\mathrm{n}=31,16.7 \% ; P<.0001$ ) was significantly more frequent in the femoral group. The rate of complications arising from limb ischemia in patients with femoral arterial cannulation were reduced with use of a DPC; however, this reduction lacked statistical significance (Table E3). Of 12 patients with limb ischemia in the axillary group, the right arm was affected in 8 patients and leg ischemia occurred in 4 patients. The likely 
TABLE 2. Procedure data of the study cohort grouped by primary arterial extracorporeal life support (ECLS) access site

\begin{tabular}{|c|c|c|c|c|}
\hline Procedure details & $\begin{array}{c}\text { Total study population } \\
(\mathbf{N}=\mathbf{4 3 6})\end{array}$ & Indirect axillary $(n=250)$ & Femoral $(n=186)$ & $P$ value \\
\hline Isolated CABG & $51(11.7)$ & $28(11.2)$ & $23(12.3)$ & .7639 \\
\hline Valve repair/replacement & $131(30)$ & $73(29.2)$ & $58(31.2)$ & .6737 \\
\hline $\begin{array}{l}\text { Combined CABG/valve } \\
\text { surgery }\end{array}$ & $113(25.9)$ & $72(28.8)$ & $41(22)$ & .1225 \\
\hline Aortic aneurysm surgery & $13(3)$ & $8(3.2)$ & $5(2.7)$ & $>.9999$ \\
\hline Acute type A aortic dissection & $24(5.5)$ & $22(8.8)$ & $2(1.1)$ & $.0004^{*}$ \\
\hline HTX & $81(18.6)$ & $38(15.2)$ & $43(23.1)$ & $.0460 *$ \\
\hline Congenital heart disease & $6(1.4)$ & $2(4)$ & $4(2.2)$ & .4088 \\
\hline Other & $17(3.9)$ & $7(2.8)$ & $10(5.4)$ & .2125 \\
\hline Procedure duration (hh:mm) & $8: 08(6: 15-10: 00)$ & $8: 40(6: 45-10: 15)$ & $7: 27(5: 34-9: 19)$ & $<.0001 *$ \\
\hline CPB (min) & $242(175.3-321.8)$ & $262(191-333)$ & $219(155.0-296.0)$ & $.0002 *$ \\
\hline Xclamp (min) & $102(71.3-154)$ & $114(80-162.5)$ & $94.5(65.8-135.8)$ & $.0010 *$ \\
\hline IABP & $37(8.5)$ & $13(5.2)$ & $24(12.9)$ & $.0052 *$ \\
\hline
\end{tabular}

Values are presented as median (interquartile range) for continuous variables and absolute numbers (n) for categorical variables. $C A B G$, Coronary artery bypass graft; $H T X$, heart transplantation; $C P B$, cardiopulmonary bypass time; Xclamp, aortic crossclamp time; IABP, intra-aortic balloon pump. *Significantly different.

origin/pathomechanism of limb ischemia in patients with axillary arterial cannulation, as well as resulting morbidity, is described in detail in Table E4. Moreover, wound healing disorders requiring surgical intervention were significantly more frequent in the femoral group (Table 3).

Of a total of 32 cases of stroke with MRS $\geq 4$ in the study cohort, localization was right hemispheric in the majority of cases $(n=20 ; 62.5 \%)$, left hemispheric $(n=5 ; 15.6 \%)$, bilateral $(\mathrm{n}=5 ; 15.6 \%)$, and infratentorial $(\mathrm{n}=2$; $6.25 \%$ ) (see Table 4 and Figure 3).

Comparing baseline and periprocedural data of patients with $(\mathrm{n}=32)$ and without $(\mathrm{n}=404)$ fatal/disabling stroke, patients with severe stroke had significantly longer ECLS run duration $(P=.034)$, longer aortic Xclamp time during main surgery $(P=.004)$, higher rates of primary axillary arterial cannulation $(P=.0003)$, aortic surgery $(P=.043)$, and CPR before implantation $(P=.174)$. All results of the bivariate analysis are depicted in Table E5. To identify risk factors for fatal/disabling stroke, the following variables were included in a multivariable binary logistic regression model: ECLS run duration, aortic Xclamp time, initial arterial cannulation site, and aortic surgery.

Primary axillary arterial ECLS cannulation was identified as the strongest risk factor for severe stroke with an adjusted odds ratio of 4.51. Additionally, ECLS duration and aortic Xclamp time were identified as risk factors (Table 5).

\section{DISCUSSION}

PC-ECLS is often a rescue therapy for patients with cardiopulmonary failure after cardiac surgery not amenable to conservative measures, which is reflected by a tremendously high mortality. Previous studies report in-hospital survival rates after PC-ECLS ranging from $25 \%$ to $46 \% .^{6-11}$ In our study cohort, survival after 1 year from PC-ECLS implantation was $42.5 \%$ in patients with primary axillary cannulation, and $44.8 \%$ in patients with primary femoral cannulation.

Although patients requiring PC-ECLS may have little or no chance to survive without temporary circulatory support, ECLS itself poses a considerable source of related complications that for themselves carry a high burden of morbidity and mortality. ${ }^{21,22}$ These ECLS-related complications might be partly related to general and often inevitable circumstances of ECLS such as increased risk of surgical site bleeding under systemic anticoagulation, but others might be preventable and represent a vantage point for improving the outcome of patients on PCECLS, such as complications related to the choice of cannulation site.

In the present study we evaluated 2 different peripheral arterial cannulation strategies for PC-ECLS in a cohort of 436 patients treated at a single center in terms of survival and incidence of cerebral and access-site-related adverse events. Although femoral arterial cannulation is a commonly used access site at many centers, indirect axillary artery cannulation has evolved to be a preferred arterial access site for PC-ECLS at our center for the benefit of predominantly antegrade body perfusion, avoidance of lower limb ischemia, as well as reduction of differential hypoxemia (ie, Harlequin effect) in patients with impaired pulmonary function. ${ }^{15,16,23}$ A reported high rate of hyperperfusion syndrome in axillary cannulation ${ }^{24}$ can be addressed easily by application of a silicone vessel loop distal to the cannulation site and biradial invasive blood pressure monitoring to enable regulation of distal blood flow. 
TABLE 3. Extracorporeal life support (ECLS) indications, run details, and adverse event rates of the study cohort grouped by primary arterial ECLS access site

\begin{tabular}{|c|c|c|c|c|}
\hline Variable & Total study cohort $(N=436)$ & Indirect axillary $(n=250)$ & Femoral $(n=186)$ & $P$ value \\
\hline \multicolumn{5}{|l|}{ ECMO indication } \\
\hline $\begin{array}{l}\text { CPB weaning failure } \\
\text { (implanted during initial } \\
\text { surgery) }\end{array}$ & $321(73.6)$ & $188(75.2)$ & $133(71.5)$ & .4419 \\
\hline $\begin{array}{l}\text { Hemodynamic decline/ } \\
\text { CPR/respiratory failure } \\
\text { after cardiac surgery } \\
\text { (implanted within } 72 \mathrm{~h} \\
\text { after end of surgery) }\end{array}$ & $115(26.4)$ & $62(24.8)$ & $53(28.5)$ & .4419 \\
\hline \multicolumn{5}{|l|}{ ECLS run details } \\
\hline CPR before implant & $92(21.1)$ & $42(16.8)$ & $50(26.9)$ & $.0126^{*}$ \\
\hline $\begin{array}{l}\text { Implant during ongoing } \\
\text { CPR }\end{array}$ & $25(5.7)$ & $5(2)$ & $20(10.8)$ & $.0001 *$ \\
\hline Duration of support (d) & $4.31(2.71-6.7)$ & $4.64(2.91-7.09)$ & $4(2.52-6.13)$ & $.0442 *$ \\
\hline $\begin{array}{l}\text { Reimplantation after } \\
\text { weaning }\end{array}$ & $25(5.7)$ & $15(6)$ & $10(5.4)$ & .8377 \\
\hline \multicolumn{5}{|l|}{ Outcome } \\
\hline In-hospital mortality & $219(50.2)$ & $128(51.2)$ & $91(48.9)$ & \\
\hline Length of hospital stay (d) & $39.2(28.4-69.4)$ & $39.9(29.1-77.1)$ & $36.7(27.9-63.3)$ & .3340 \\
\hline \multicolumn{5}{|l|}{ ECLS-related complications } \\
\hline Any stroke & $48(11)$ & $41(16.4)$ & $7(3.8)$ & $<.0001 *$ \\
\hline MRS 1 & $9(18.8)$ & $7(17.1)$ & $2(28.6)$ & \\
\hline MRS 2 & $3(6.3)$ & $3(7.3)$ & $0(0)$ & \\
\hline MRS 3 & $4(8.3)$ & $3(7.3)$ & $1(14.3)$ & \\
\hline MRS 4 & $11(22.9)$ & $10(24.4)$ & $1(14.3)$ & \\
\hline MRS 5 & $3(6.3)$ & $3(7.3)$ & $0(0)$ & \\
\hline MRS 6 & $18(37.5)$ & $15(36.6)$ & $3(42.9)$ & \\
\hline Stroke MRS $\geq 2$ & $39(8.9)$ & $34(13.6)$ & $5(2.7)$ & $<.0001 *$ \\
\hline Stroke MRS $\geq 4$ & $32(7.3)$ & $28(11.2)$ & $4(2.2)$ & $.0003 *$ \\
\hline Ischemic & $23(5.3)$ & 19 (7.6) & $4(2.2)$ & $.0155^{*}$ \\
\hline Hemorrhagic & $9(2.1)$ & $9(3.6)$ & $0(0)$ & $.0120^{*}$ \\
\hline $\begin{array}{l}\text { Major cannulation site } \\
\text { bleeding }\end{array}$ & $59(13.5)$ & 34 (13.6) & $25(13.4)$ & $>.9999$ \\
\hline Limb ischemia & $43(9.9)$ & $12(4.8)$ & $31(16.7)$ & $<.0001 *$ \\
\hline Fasciotomy & $21(4.8)$ & $8(3.2)$ & $13(7)$ & .0743 \\
\hline Limb amputation & $5(1.1)$ & $2(0.8)$ & $3(1.6)$ & .6550 \\
\hline Arm hyperperfusion & $5(1.1)$ & $5(2)$ & $0(0)$ & .0746 \\
\hline $\begin{array}{l}\text { Wound healing disorder/ } \\
\text { lymphocele (cannulation } \\
\text { site) }\end{array}$ & $44(10.1)$ & $10(4)$ & $34(18.2)$ & $<.0001 *$ \\
\hline Change of cannulation site & $36(8.3)$ & 19 (7.6) & $17(9.1)$ & .6002 \\
\hline $\begin{array}{l}\text { Change of cannulation site } \\
\text { for bleeding }\end{array}$ & $15(3.4)$ & $13(5.2)$ & $2(1.1)$ & $.0301 *$ \\
\hline $\begin{array}{l}\text { Change of cannulation site } \\
\text { for limb ischemia }\end{array}$ & $10(2.3)$ & $3(1.2)$ & $7(3.8)$ & .1059 \\
\hline $\begin{array}{l}\text { Arterial cannula } \\
\text { accidentally displaced }\end{array}$ & $5(1.1)$ & $2(0.8)$ & $3(1.6)$ & .6550 \\
\hline Cannula/device thrombosis & $15(3.4)$ & $11(4.4)$ & $4(2.2)$ & .2891 \\
\hline $\begin{array}{l}\text { Leg cannula displaced/ } \\
\text { obstructed }\end{array}$ & $38(8.7)$ & $3(1.2)$ & $35(18.8)$ & $<.0001 *$ \\
\hline Aortic dissection & $2(0.5)$ & $0(0)$ & $2(1.1)$ & .1814 \\
\hline
\end{tabular}

Values are presented as median (interquartile range) for continuous variables and absolute numbers (\%) for categorical variables. $E C M O$, Extracorporeal membrane oxygenation; $C P B$, cardiopulmonary bypass time; $C P R$, cardiopulmonary resuscitation; $E C L S$, extracorporeal life support; $M R S$, modified ranking scale. *Significantly different. 


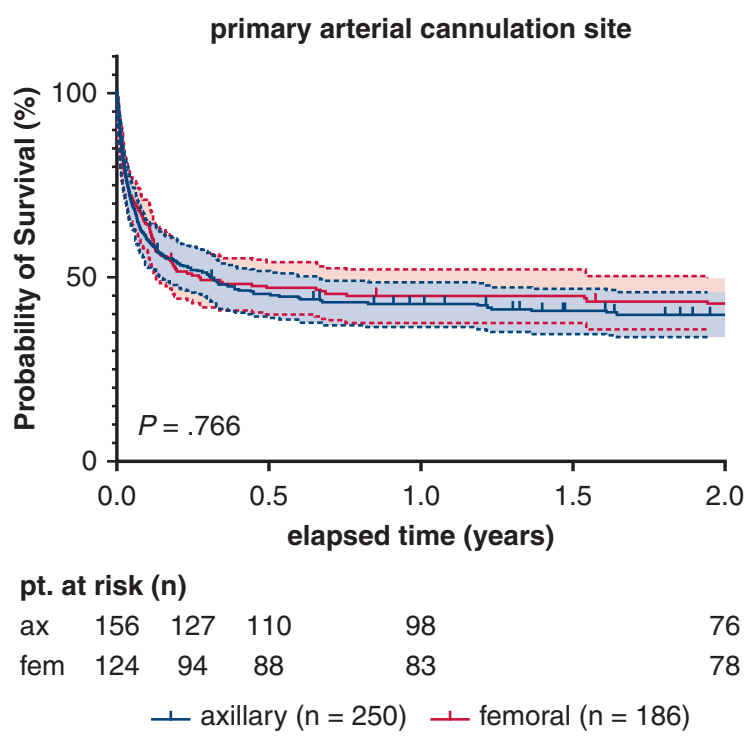

FIGURE 2. Kaplan-Meier estimates of survival. Survival in patients with axillary (ax) and femoral (fem) arterial extracorporeal life support (ECLS) cannulation is visualized by Kaplan-Meier curves, and survival compared between the groups by $\log$ rank test. There was no significant difference in survival between patients with ax and fem primary arterial ECLS access site (ax vs fem $P=.766$ ). The shaded areas represent the $95 \%$ CI.

In the setting of $\mathrm{CPB}$ weaning failure where a direct switch from CPB to ECLS is conducted, there is usually enough time to allow the more time-consuming indirect axillary artery cannulation. In emergency situations or whenever rapid initiation of ECLS is required, the femoral artery is still the preferred access site.

Although survival did not differ between axillary and femoral arterial cannulation in our study (30-day survival: axillary: $62 \%$ vs femoral: $64.7 \%$ ) we found a different spectrum and incidence of access-site-related adverse events. In particular, we observed a significantly higher rate of severe stroke in patients cannulated via the right axillary artery (axillary: $11.2 \%$ vs femoral: $2.2 \%$ ), predominantly these strokes were located in the right hemisphere. Pisani and colleagues ${ }^{25}$ described a low incidence of local complications in axillary arterial cannulation in a mixed cohort of PC and non-PC ECLS patients; however, cerebral complications were not assessed. Toivonen and colleagues $^{12}$ found that neurologic injury (ischemic or hemorrhagic stroke) is a common complication in PCECLS patients with a reported incidence as high as $19 \%$ and associated with adverse outcome in a multicenter meta-analysis of 781 PC-ECLS patients; however, the influence of the arterial access site was not addressed.

Hypotheses for the high incidence of right hemispheric strokes are the anatomical proximity of the cannulation site together with flow turbulences at the anastomosis site. Especially in patients with smaller subclavian arteries and higher flow requirements, this might play an underestimated role.

On the other hand, in some cases there is a chronological relation between ECLS weaning and onset of stroke (Table E6), although due to the retrospective design of the study, we could not prove this point. Nevertheless, it is recommended not to keep the patient on lower flow for a too-long time period.

Measures to avoid thromboembolism during explant include proximal clamping of the subclavian/axillary artery during the explant procedure; however, this does not protect against thromboembolism from the cannulation site during the ECLS run. Based on the results of the present analysis, we consider it important to implement a standard operating procedure for axillary ECLS explant because a relevant proportion of major strokes seem to be in relation to the explant procedure. However, we emphasize that we cannot yet tell whether or not these measures are able to mitigate the occurrence of stroke in any way, and this must be subject of future studies. We suggest achieving proximal and distal control of the axillary artery before stopping ECLS and excluding the vessel from circulation. The cannula should then be removed, and the graft inspected for any thrombus formation, which is removed carefully. If a thrombus is present in the graft, a thrombectomy should then be performed from distally and proximally, before the artery is unclamped, the graft flushed in a retrograde fashion and ligated. To avoid thrombus formation at the cannulation site, adequate anticoagulation should be maintained, especially during the weaning phase, and a structured weaning protocol followed to avoid prolonged low-flow promoting thrombus formation during this phase. Because ECLS duration was also identified as a risk factor for stroke in this study, another important conclusion is that explantation of ECLS should never be unnecessarily delayed (eg, for

TABLE 4. Stroke localization

\begin{tabular}{|c|c|c|c|c|c|}
\hline $\begin{array}{l}\text { Primary arterial } \\
\text { cannulation site }\end{array}$ & $\begin{array}{c}\text { Total No. of patients with } \\
\text { stroke MRS } \geq 4\end{array}$ & Right hemispheric & Left hemispheric & Bilateral & Infratentorial \\
\hline $\begin{array}{l}\text { Total study population } \\
\qquad(\mathrm{N}=436)\end{array}$ & $32(7.3)$ & $20(62.5)$ & $5(15.6)$ & $5(15.6)$ & $2(6.25)$ \\
\hline Axillary artery $(\mathrm{n}=250)$ & $28(11.2)$ & $18(64.3)$ & $4(14.3)$ & $4(14.3)$ & $2(7.1)$ \\
\hline Femoral artery $(\mathrm{n}=186)$ & $4(2.2)$ & $2(50)$ & $1(25)$ & $1(25)$ & $0(0)$ \\
\hline
\end{tabular}

Values are presented as absolute numbers (\%). MRS, Modified ranking scale. 


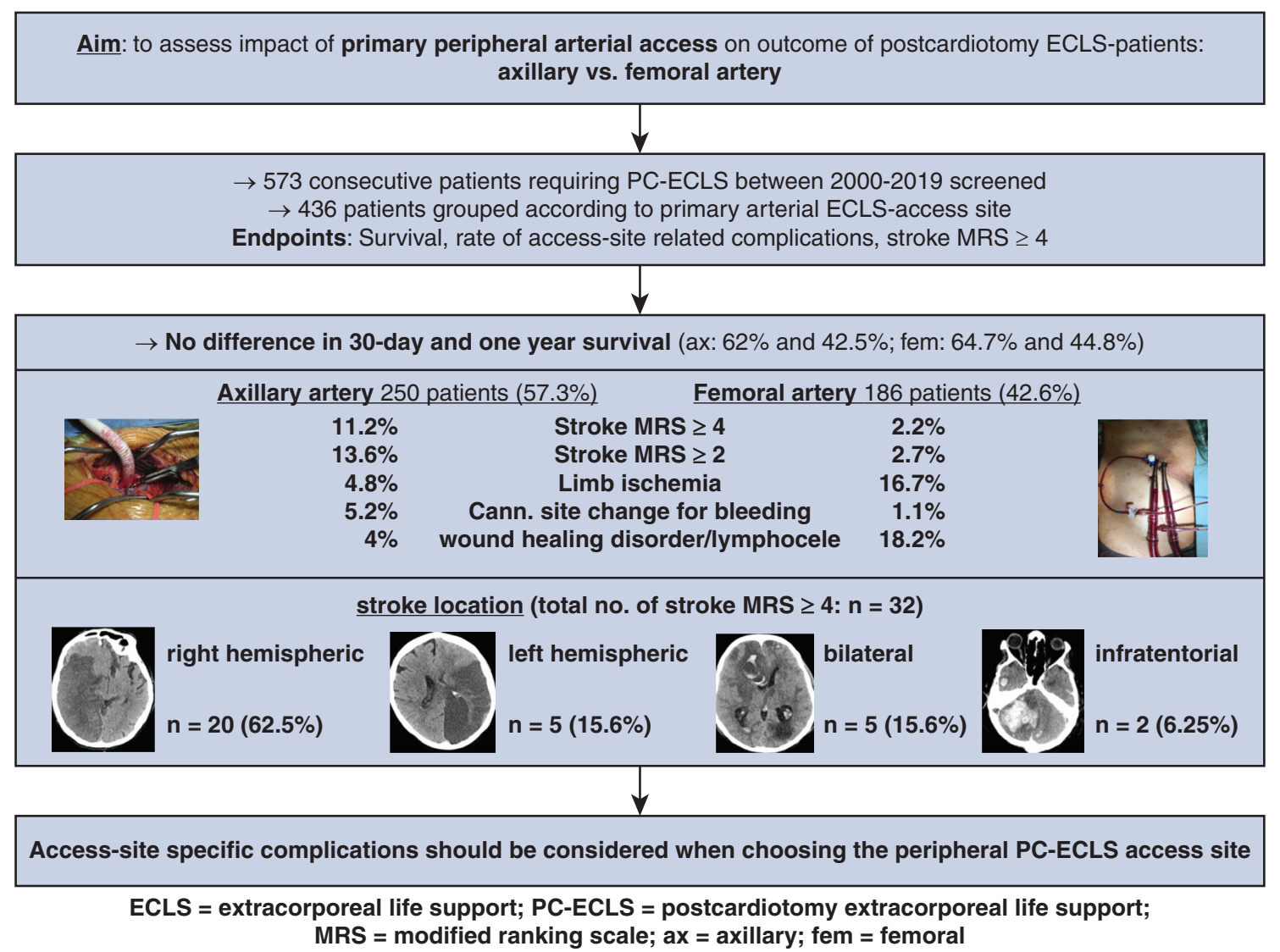

FIGURE 3. The aim of the present study (section 1), the definition of the study cohort and end points (section 2), as well as the main results and conclusion of the study (sections 3 and 4). Although no difference in survival between patients with femoral (fem) and axillary (ax) arterial extracorporeal life support $(E C L S)$ cannulation was observed, the rate of stroke and cannulation site change for bleeding was significantly higher in the axillary group, whereas the incidence of limb ischemia and cannulation site wound healing disorders was significantly higher in the femoral group. The distribution of stroke localization in 32 patients with stroke with a modified ranking scale $(M R S) \geq 4$ is shown. $P C$-ECLS, Postcardiotomy extracorporeal life support.

logistic reasons) because longer ECLS run duration may increase the risk for adverse events and also for mortality, which has already been suggested by the results of previous studies, ${ }^{26,27}$ and was also confirmed in the present study. Explantation of indirect axillary cannulated ECLS following the abovementioned standard operating procedure is uncomplicated and can be performed in the intensive care unit in most cases, thus not requiring any operating

TABLE 5. Risk factors for stroke modified ranking scale (MRS) $\geq 4$ were identified using a binary logistic regression model, including clinically relevant and significant parameters from the bivariate analysis

\begin{tabular}{lcc}
\hline \multicolumn{1}{c}{ Risk factor } & $\begin{array}{c}\text { Adjusted odds } \\
\text { ratio }(\mathbf{9 5} \% \mathbf{C I})\end{array}$ & $\boldsymbol{P}$ value \\
\hline Duration of ECLS (d) & $1.08(1.00-1.15)$ & .0332 \\
Xclamp (min) & $1.00(1.00-1.01)$ & .0323 \\
Initial cannulation & $4.51(1.69-15.63)$ & .0064 \\
$\quad$ site = axillary & & .3305 \\
\hline Aortic surgery & $1.67(0.55-4.41)$ &. \\
\hline
\end{tabular}

ECLS, Extracorporeal membrane oxygenation; Xclamp, aortic crossclamp time. room capacity. Potentially, stroke incidence can be reduced by strictly adhering to these measures; however, surgeons should be aware of the specific risk in axillary cannulation.

We observed no significant difference in cannulation site bleeding requiring surgical revision; however, change of cannulation site for severe bleeding was significantly more frequent in the axillary group. This may suggest that bleeding at the axillary cannulation site can be more difficult to manage and treat with success, thus requiring change to another site more frequently. This finding is in line with the results of previous studies investigating axillary ECLS cannulation. ${ }^{24}$ Of note, bleeding at the axillary cannulation site and hematoma formation can lead to malperfusion of the right arm and a vicious circle causing further complications, and this was the cause of upper extremity ischemia in 5 of 12 patients with extremity ischemia in the axillary cannulation group in our study (Table 5).

As expected, we saw a significantly higher rate of clinically apparent limb ischemia in the group with femoral cannulation, and the rate of limb ischemia necessitating cannulation site change was more frequent in the femoral 
group. This was to be expected; however, rates of severe associated complication such as fasciotomy and amputation were similar in both groups.

There was a visible reduction of limb ischemia and associated complications with the use of a DPC in our study; however, these reductions missed statistical significance and the study was probably underpowered to prove a benefit of DPC utilization. Additionally, although it became standard to implant a DPC at the time of ECLS implantation within recent years, this was not the case in earlier years where DPCs were often only implanted with already apparent clinical limb ischemia (Table E3).

We believe that DPC placement right at the time of femoral ECLS implantation, as well as close clinical monitoring of the extremity to detect limb ischemia before complications arise, is of paramount importance and may be able to reduce the problem of severe limb complications with femoral ECLS cannulation. Furthermore, it is important to understand that axillary cannulation likewise carries a risk of limb complications, often related to cannulation site bleeding and subsequent impaired perfusion of the arm (Table E4).

Despite the higher incidence of stroke, survival in the axillary group was the same as in the femoral group. The reasons for this might be that the femoral cannulation strategy has other disadvantages like the higher incidence of leg ischemia and the higher left ventricular afterload together with poorer oxygenation of the upper body. Therefore, according to our data, we cannot clearly recommend one cannulation site over the other but obviously the occurrence of major stroke is a relevant obstacle of the right axillary artery as cannulation site. Limb complications occurring with femoral access can be reduced by DPC utilization and close clinical monitoring. Furthermore, it should be emphasized that limb complications are not limited to femoral access but also occur in axillary cannulation, often as a consequence of cannulation site bleeding and hematoma formation. Pros and cons of each cannulation site need to be taken into consideration for each individual patient. Additionally, the quality of cannulation in each technique is highly dependent on the ECLS implanting surgeon. Attention must be paid to every detail: appropriate cannula selection, meticulous performance of the anastomoses of the graft to the axillary artery, as well as protection of leg perfusion in case of femoral arterial cannulation are essential. Anastomosis site bleeding as well as thrombus formation within the system need to be avoided, because a technically not optimally implanted ECLS might be the source of severe complications regardless of the site of cannulation.

Nevertheless, our study shows that the primary access site can significantly influence the outcome of an individual patient. In our eyes, a prospective randomized trial comparing arterial ECLS access would be justified and necessary. Moreover, other options for primary access site need to be addressed such as cannulation of the left instead of the right subclavian artery, indirect femoral cannulation with a site graft, and even direct cannulation of the axillary artery in comparison to the indirect option.

\section{Limitations}

The retrospective design and potential for a historical bias are inherent to the present study because indirect axillary cannulation evolved to be the preferred access site at out center within the recent years, whereas femoral cannulation was more common in earlier years (Figure E1). Axillary cannulation is mostly used for ECLS access in controlled situations, such as weaning failure from $\mathrm{CPB}$, allowing for cannulation while the patient is still on CPB, whereas femoral access naturally is preferred in emergency settings. Also, the management of ECLS patients in an intensive care unit is likely to have changed over time. A randomized trial evaluating different peripheral ECLS access sites for postcardiotomy ECLS is justified. Whereas preceding ECLS related events leading to stroke were detectable in some of the patients, it is not possible in every case to differentiate between perioperative and ECLS related origin of strokes in a retrospective study, especially in patients undergoing procedures with a high risk of perioperative stroke, such as patients with aortic dissections. Furthermore, strokes without clinical neurological symptoms in sedated patients were not apprehended because no routine CCTs were performed in absence of clinical neurological deficits.

\section{CONCLUSIONS}

Surgeons should be aware of different complication profiles when choosing peripheral arterial access site for postcardiotomy ECLS. Although lower rates of limb ischemia and the advantage of antegrade flow seem beneficial for axillary cannulation, especially the high incidence of right hemispheric strokes in axillary artery cannulation should be considered.

\section{Webcast}

You can watch a Webcast of this AATS meeting presentation by going to: https://aats.blob.core.windows.net/ media/21\%20AM/AM21_A56/AM21_A56_07.mp4.

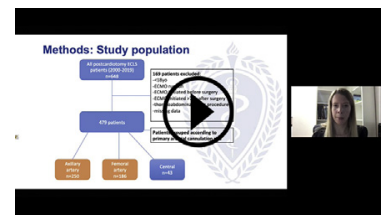

\section{Conflict of Interest Statement}

Dr Wiedemann is a proctor for Abbott and Medtronic. All other authors reported no conflicts of interest. 
The Journal policy requires editors and reviewers to disclose conflicts of interest and to decline handling or reviewing manuscripts for which they may have a conflict of interest. The editors and reviewers of this article have no conflicts of interest.

\section{References}

1. McCarthy FH, McDermott KM, Kini V, Gutsche JT, Wald JW, Xie D, et al. Trends in U.S. extracorporeal membrane oxygenation use and outcomes: 20022012. Semin Thorac Cardiovasc Surg. 2015;27:81-8.

2. Lorusso R, Raff GM, Alenizy K, Sluijpers N, Makhoul M, Brodie D, et al. Structured review of post-cardiotomy extracorporeal membrane oxygenation: part 1Adult patients. J Heart Lung Transplant. 2019;38:1125-43.

3. Whitman GJ. Extracorporeal membrane oxygenation for the treatment of postcardiotomy shock. J Thorac Cardiovasc Surg. 2017;153:95-101.

4. Lorusso R, Whitman G, Milojevic M, Raffa G, McMullan DM, Boeken U, et al. 2020 EACTS/ELSO/STS/AATS expert consensus on post-cardiotomy extracorporeal life support in adult patients. J Thorac Cardiovasc Surg. 2021;59:12-53.

5. Saeed D, Potapov E, Loforte A, Morshuis M, Schilbilsky D, Zimpfer D, et al Transition from temporary to durable circulatory support systems. J Am Coll Cardiol. 2020;76:2956-64.

6. Biancari F, Perotti A, Ruggieri VG, Mariscaloco G, Dalen M, Dell'Aquila AM, et al. Five-year survival after post-cardiotomy veno-arterial extracorporeal membrane oxygenation. Eur Heart J Acute Cardiovasc Care. 2021;10:595-601.

7. Biancari F, Dalen M, Fiore A, Ruggieri VG, Saeed D, Johsson K, et al. Multicenter study on postcardiotomy venoarterial extracorporeal membrane oxygenation. J Thorac Cardiovasc Surg. 2020;159:1844-54.e6.

8. Khorsandi M, Dougherty S, Bouamra O, Pai V, Curry P, Tsui S, et al. Extracorporeal membrane oxygenation for refractory cardiogenic shock after adult cardiac surgery: a systematic review and meta-analysis. J Cardiothorac Surg. 2017:12:55.

9. Rastan AJ, Dege A, Mohr M, Doll N, Falk V, Walther T, et al. Early and late outcomes of 517 consecutive adult patients treated with extracorporeal membrane oxygenation for refractory postcardiotomy cardiogenic shock. J Thorac Cardiovasc Surg. 2010;139:302-11. 311.e1.

10. Meani P, Matteucci M, Jiritano F, Fina D, Panzeri F, Raffa GM, et al. Long-term survival and major outcomes in post-cardiotomy extracorporeal membrane oxygenation for adult patients in cardiogenic shock. Ann Cardiothorac Surg. 2019;8:116-22.

11. Chen F, Wang L, Shao J, Wang H, Hou X, Jia M. Survival following venoarterial extracorporeal membrane oxygenation in postcardiotomy cardiogenic shock adults. Perfusion. 2020;35:747-55.

12. Toivonen F, Biancari F, Dalen M, Dell'Aquila AM, Jonsson K, Fiore A, et al. Neurologic injury in patients treated with extracorporeal membrane oxygenation for postcardiotomy cardiogenic shock. J Cardiothorac Vasc Anesth. 2021;35: 2669-80.

13. Wilcox C, Etchill E, Guiliano K, Mayasi Y, Gudson AM, Choi CW, et al. Acute brain injury in postcardiotomy shock treated with venoarterial extracorporeal membrane oxygenation. J Cardiothorac Vasc Anesth. 2021;35:1989-96.

14. Mariscalco G, Salsano A, Fiore A, Dalen M, Ruggieri V, Saeed D, et al. Peripheral versus central extracorporeal membrane oxygenation for postcardiotomy shock: multicenter registry, systematic review, and meta-analysis. J Thorac Cardiovasc Surg. 2020;160:1207-16.e44.

15. Buchtele N, Staudinger T, Schwameis M, Schorgenhofer C, Herkner H, Hermann A, et al. Feasibility and safety of watershed detection by contrastenhanced ultrasound in patients receiving peripheral venoarterial extracorporeal membrane oxygenation: a prospective observational study. Crit Care. 2020;24: 126.

16. Honore PM, Gutierrez LB, Kugener L, Redant S, Attou R, Gallerani A, et al. Risk of harlequin syndrome during bi-femoral peripheral VA-ECMO: should we pay more attention to the watershed or try to change the venous cannulation site? Crit Care. 2020;24:450.

17. Angleitner P, Roeggla M, Laufer G, Wiedemann D. Watershed of veno-arterial extracorporeal life support. Eur J Cardiothorac Surg. 2016;50:785.

18. Navia JL, Atik FA, Beyer EA, Vega PR. Extracorporeal membrane oxygenation with right axillary artery perfusion. Ann Thorac Surg. 2005;79:2163-5.

19. Buchtele N, Staudinger T, Schaefer A-K, Bogl MS, Schoergenhofer C, Schwameis M. Anticoagulation in critically ill adults during extracorporeal circulation. Hamostaseologie. 2021;41:294-306.
20. Lansky AJ, Messe SR, Brickman AM, Dwyer M, van der Worp HB, Lazar RM, et al. Proposed standardized neurological endpoints for cardiovascular clinical trials: an Academic Research Consortium initiative. Eur Heart J. 2018;39: 1687-97.

21. Wong JK, Melvin AL, Joshi DJ, Lee CY, Archibald Wj, Angona RE, et al. Cannulation-related complications on veno-arterial extracorporeal membrane oxygenation: prevalence and effect on mortality. Artif Organs. 2017;41:827-34.

22. Ohman JW, Vemuri C, Prasad S, Silvestri SC, Jim J, Geraghty PJ. The effect of extremity vascular complications on the outcomes of cardiac support device recipients. J Vasc Surg. 2014;59:1622-7.

23. Javidfar J, Brodie D, Costa J, Miller J, Jurrado J, LaVelle M, et al. Subclavian artery cannulation for venoarterial extracorporeal membrane oxygenation. ASAIO J. 2012:58:494-8.

24. Chamogeorgakis T, Lima B, Shafii AE, Nagpal D, Pokersnik JA, Navia JL, et al. Outcomes of axillary artery side graft cannulation for extracorporeal membrane oxygenation. J Thorac Cardiovasc Surg. 2013;145:1088-92.

25. Pisani A, Braham W, Bregga C, Lajmi M, Provenchere S, Danial P, et al. Right axillary artery cannulation for venoarterial extracorporeal membrane oxygenation: a retrospective single centre observational study. Eur J Cardiothorac Surg. 2021;59:601-9.

26. Distelmaier K, Wiedemann D, Binder C, Haberl T, Zimpfer D, Heinz G, et al. Duration of extracorporeal membrane oxygenation support and survival in cardiovascular surgery patients. J Thorac Cardiovasc Surg. 2018;155:2471-6.

27. Mariscalco G, El-Dean Z, Yusuff H, Fux T, Dell'Aquila AM, Jonsson K, et al. Duration of venoarterial extracorporeal membrane oxygenation and mortality in postcardiotomy cardiogenic shock. J Cardiothorac Vasc Anesth. 2021;35: $2662-8$.

Key Words: cardiac surgery, extracorporeal life support, venoarterial extracorporeal membrane oxygenation, peripheral ECLS cannulation, postcardiotomy ECLS

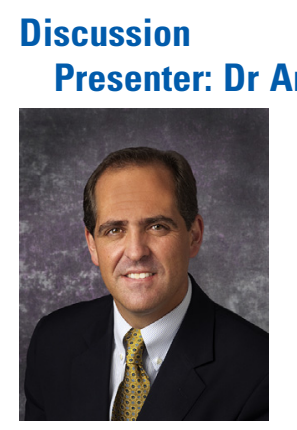

Dr Christian Andres Bermudez
(Philadelphia, Pa). I would like to
thank the American Association for
Thoracic Surgery for the opportunity
to review and discuss this research.
And I would like to thank Dr Schaefer
for sending me the manuscript and the
presentation well ahead of time for review. In this study, the University of Vienna group review the extensive experience with the use of postcardiotomy extracorporeal life support (ECLS) with the 2 most frequent peripheral cannulation strategies, meaning axillary artery cannulation and femoral cannulation. Dr Schaefer went over the results, but in the summary, there was no difference in mortality. There was a significantly higher rate of stroke in the axillary cannulation group. There was a significantly higher rate of exchange due to bleeding in the axillar cannulation strategy, and a higher rate of vascular complications in the femoral cannulation group. Axillar cannulation has stronger predictive risk for stroke in this study with an odds ratio of 4.5. The authors conclude that although survival did not differ between the cannulation strategy, surgeons should be aware of the access site's specific 
complications found in this study and they should think about it at the time of the decision process.

I have a few comments and questions. Cerebral and vascular complications are well known to be the Achilles' heel of ECLS. To my knowledge, this is the largest study comparing these 2 very different cannulation techniques, and the first to strongly associate axillary cannulation with stroke. Your results came as no surprise to me. Although the published data have been inconclusive your findings of increased risk of cerebrovascular accidents and exchange for bleeding in axillary cannulation is what I've observed in my career during the past 15 years, especially in prolong ECLS support. I have a few questions.

Your study provides an important message and I consider you should help us characterize better the patients with clinically relevant strokes, to try to understand better the mechanism leading to them and their potential prevention. This is relevant if you consider that 41 of the 48 strokes have been in the axillar cannulation group. The current definition of the neural arc used in aortic surgery has defined the disabling stroke those with a modified ranking scale (MRS) of $\geq 2$. In your study, you use MRS $\geq 4$ to define a disabling stroke that could lead to a significant underestimation of this complication. And I consider that you should report according to the new standards set in aortic surgery that were used in transcatheter aortic valve replacement trials. Could you comment on this?

Second question: To understand better the effect of surgery versus easy and less on the cause of stroke, could you clarify the time of the diagnosis of cerebrovascular accident? Especially when the computed tomography scan was performed. Was this done within 24 hours, or did this happen while the patient was on extracorporeal membrane oxygenation support for 2 to 4 days after surgery? This could help us define if this stroke was related to the perioperative event or directly attributed to ECLS.

Third question: The majority of the strokes were ischemic or embolic in origin in the axillary and in the femoral group, could you clarify your anticoagulation protocol? This was not specified. What were the activated partial thromboplastin times at the time of diagnosis of stroke? Were there any differences or deviations outside the range of anticoagulation that could have led to this embolic event?

As a final question and comment. I would like to say that finally after reading your manuscript, I was ready to conclude that femoral cannulation was better than axillary cannulation. That has been my feeling all along during my practice. This conclusion unfortunately was not possible in your study, due to the high reported rate of so-called vascular complications regarding cannular exchange in the femoral cannulation group-16\%. There was no significant difference in fasciotomies and amputation in both groups.

The rate of vascular complications has been dramatically reduced, as you know to $<5 \%$, with the use of distal perfusion catheter. Although you mention it in your article, there is no description in utilization rate of distal perfusion catheter. Could you describe the percentage rate of distal perfusion catheter in your femoral calculation group? Was there any difference in vascular complications when distal perfusion was used? And if that rate was lowered, would you be ready to say now or suggest that femoral cannulation is better than axillar calculation in postcardiotomy shock? I would like to thank you again for this interesting study.

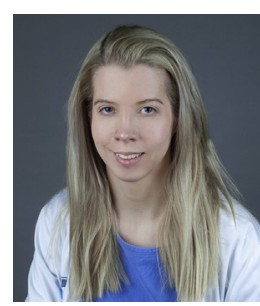

Dr Anne-Kristin Schaefer (Vienna, Austria). First of all, Dr Bermudez, thank you very much for the summary and also for sharing your experience with axillary and femoral ECLS cannulation. Your first question was about the definition of fatal, disabling stroke. We used the MRS of 4 and above and it's sometimes a little bit difficult with a retrospective cohort to really define the neurology of the patient and the severity of stroke, especially in a postoperative patient who cannot be fully clinically assessed due to sedation and other factors related to the postoperative phase. However, I think it is worth looking into our data again to have a more granular definition of stroke and also include patients with MRS of 2 and above. Regarding the timing of stroke, it's also the same problems in the retrospective cohort because computed tomography scans are often performed with a delay.

For example, when the patient wakes up with a neurology that is not okay you bring them to computed tomography, and you see that they have a severe stroke. And we also observed a chronological relation sometimes to the explanation of ECLS. So, we can only hypothesize that many of these strokes happen during the explant process potentially caused by embolism and also strongly related to the duration of ECLS because duration of ECLS has also been identified as a risk factor of stroke in our article.

Dr Bermudez. For that same reason, I made this comment because I noticed your comment regarding that this happened at the time of decannulation. It would be interesting to find in your article a way to time this, or the computed tomography scan, or some sort of suspicion of stroke versus delay at the time of decannulation and put it more clearly because that's an important message. Especially if this happened late when you're decannulating and we couldn't find any information on that in the article.

Dr Benjamin Sun (Minneapolis, Minn). Can I also ask, is the cannulation strategy percutaneous for axillary or versus cut-down and sewing a graft on?

Dr Schaefer. All the axillary cannulations were with a cut down and indirect cannulation by a graft that is sewn on the axillary artery. And femoral cannulation was percutaneous. 
Dr Bermudez. Regarding the anticoagulation, Dr Schaefer, I was interested in hearing about it because there was no clear definition of that, and I wanted to see if there was any correlation with anticoagulation and embolic events.

Dr Schaefer. In most cases, unfractionated heparin was used with a therapeutic activated partial thromboplastin time. However, our patients are spread out on different intensive care units and every intensive care unit has their own management strategies, which is obviously a limitation of the study. And in the postoperative patients, there are variations in that because when the patient has mediastinal bleeding, for example, anticoagulation will be paused. It's also difficult to assess. However, we could try to look at the data.

Dr Bermudez. It would be interesting at least to know if they were receiving heparin because very often after surgery you wean them off heparin. I would be interested to know if they were receiving heparin and stroked or if they were not on heparin and then they stroked.

And the last point that was really curious and would make the difference between the 2 techniques, the use of distal perfusion catheter. Because if you use only $20 \%$ and your rate of vascular complications rise because of that, well you can fix that. And that immediately makes femoral cannulation a better strategy. Different to what you suggest in your study.

Dr Schaefer. In recent years we use a peripheral perfusion catheter in almost every case. We tried to implement it already at the time of placing the ECLS and I have the feeling that because we do that, the rate of vascular complications has decreased. However, in earlier years we did not do that in every patient and many patients got a distal perfusion catheter only with a delay when they already have a vascular problem. I think if you do it in every patient you can tremendously ameliorate the results.

Dr Bermudez. Going back to your conclusion: If you have a reported rate of vascular complication of $4 \%$ to $5 \%$ with distal perfusion using femoral cannulation then you have no difference in survival between the 2 techniques while you have more bleeding with axillar cannulation, and no difference in vascular complications. That, for me, makes peripheral femoral cannulation a better strategy. This difference could change eventually, or could help better characterize your findings. 


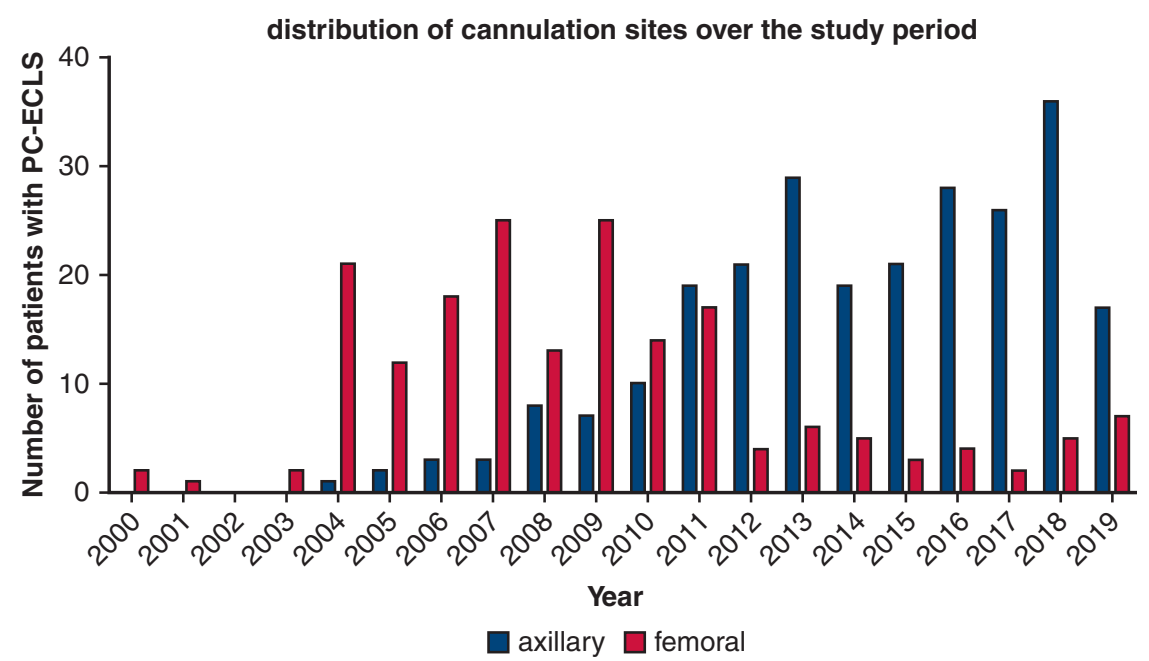

FIGURE E1. Histogram showing the utilization of axillary and femoral arterial postcardiotomy extracorporeal life support $(P C$ - $E C L S)$ cannulation over the study period. 
TABLE E1. Baseline and periprocedure data of patients who died $(n=219)$ and who survived until hospital discharge $(n=217)$

\begin{tabular}{|c|c|c|c|c|}
\hline Periprocedure data & $\begin{array}{c}\text { Total study } \\
\text { population }(N=436)\end{array}$ & Survivors $(\mathbf{n}=217)$ & Nonsurvivors $(\mathrm{n}=\mathbf{2 1 9})$ & $P$ value \\
\hline Age $(y)$ & $67.0(57.2-73.8)$ & $64.3(54.1-77.8)$ & $68.6(60.7-76.3)$ & $<.0001 *$ \\
\hline Male & $287(65.8)$ & $154(71)$ & $133(60.7)$ & $.0265 *$ \\
\hline EuroSCORE II & $14.2(5.9-30.9)$ & $10.5(4.5-22.1)$ & $17(7-35.9)$ & $.0002 *$ \\
\hline BMI & $26.8(24.0-30.0)$ & $26.6(23.7-29.4)$ & $26.8(24.2-30.8)$ & .1327 \\
\hline Hypertension & $312(71.6)$ & $154(71)$ & $158(72)$ & .8321 \\
\hline Hypercholesterolemia & $236(54.1)$ & $121(55.8)$ & $115(52.5)$ & .5028 \\
\hline $\begin{array}{l}\text { Insulin-dependent diabetes } \\
\text { mellitus }\end{array}$ & $32(7.3)$ & $14(6.5)$ & $18(8.2)$ & .5824 \\
\hline Coronary artery disease & $243(55.7)$ & $121(55.8)$ & $122(55.7)$ & $>.9999$ \\
\hline Creatinine (mg/dL) & $1.3(1-1.8)$ & $1.2(1-1.7)$ & $1.3(1.1-1.8)$ & $.0392 *$ \\
\hline $\begin{array}{l}\text { Estimated glomerular } \\
\text { filtration rate } \\
\left(\mathrm{mL} / \mathrm{min} / 1.73 \mathrm{~m}^{2}\right)\end{array}$ & $57.4(39.4-79)$ & $62.3(46.1-84.9)$ & $52.1(36-72)$ & $.0003 *$ \\
\hline Blood urea nitrogen (mg/dL) & $24(17-36.8)$ & $22(16-32)$ & $25.8(18.4-42)$ & $.0066^{*}$ \\
\hline Total bilirubin (mg/dL) & $1(0.6-1.2)$ & $1(0.5-1.0)$ & $1(0.7-1.7)$ & $.0134 *$ \\
\hline ASAT (U/L) & $30(22-52.3)$ & $29(22-51.8)$ & $31(22.3-52.8)$ & .2967 \\
\hline ALAT (U/L) & $26(18-43)$ & $27(17-43)$ & $26(18-43)$ & .9757 \\
\hline Gamma-GT (U/L) & $59(33-104)$ & $54(29-97)$ & $61(35-124.5)$ & .0739 \\
\hline Hemoglobin (mg/dL) & $12(10.3-13.9)$ & $12.4(11-14)$ & $12(10-13.2)$ & $.0164 *$ \\
\hline C-reactive protein $(\mathrm{mg} / \mathrm{dL})$ & $1(0.1-4)$ & $1(0.1-2.7)$ & $1(0.2-5)$ & .0598 \\
\hline Peripheral arterial disease & $61(14)$ & $27(12.4)$ & $34(15.5)$ & .4080 \\
\hline Cerebrovascular disease & $62(14.2)$ & $24(11.1)$ & $38(17.4)$ & .0742 \\
\hline Previous stroke/TIA & $74(17)$ & $32(14.7)$ & $42(19.2)$ & .2512 \\
\hline Previous cardiac surgery & 139 (31.9) & $68(31.3)$ & $71(32.4)$ & .8375 \\
\hline Active endocarditis & $46(10.6)$ & $19(8.8)$ & $27(12.3)$ & .2753 \\
\hline $\begin{array}{l}\text { ECMO indication } \\
\text { CPB weaning failure } \\
\text { (implanted during initial } \\
\text { surgery) }\end{array}$ & 321 (73.6) & $160(73.7)$ & $161(73.5)$ & $>.9999$ \\
\hline $\begin{array}{l}\text { Hemodynamic decline/ } \\
\text { CPR/respiratory failure } \\
\text { after cardiac surgery } \\
\text { (implanted within } 72 \mathrm{~h} \\
\text { after end of surgery) }\end{array}$ & $115(26.4)$ & $57(26.3)$ & $58(26.5)$ & \\
\hline Duration of support (d) & $4.31(2.71-6.7)$ & $3.6(2.52-5.51)$ & $5.2(3.1-8.2)$ & $<.0001$ \\
\hline $\begin{array}{l}\text { Initial arterial cannulation site } \\
\text { Axillary } \\
\text { Femoral }\end{array}$ & $\begin{array}{l}250(57.3) \\
186(42.7)\end{array}$ & $\begin{array}{r}122(56.2) \\
95(43.8)\end{array}$ & $\begin{array}{r}128(58.4) \\
91(41.6)\end{array}$ & .6986 \\
\hline Procedure performed & & & & $.0003 *$ \\
\hline Isolated CABG & $51(11.7)$ & $32(14.7)$ & $19(8.7)$ & \\
\hline Valve repair/replacement & $131(30)$ & $55(25.3)$ & $76(34.7)$ & \\
\hline $\begin{array}{l}\text { Combined CABG/valve } \\
\text { surgery }\end{array}$ & 113 (25.9) & $46(21.2)$ & $67(30.6)$ & \\
\hline Aortic surgery & $37(8.5)$ & $18(8.3)$ & $19(8.7)$ & \\
\hline HTX & $81(18.6)$ & $57(26.3)$ & $24(11)$ & \\
\hline Congenital heart disease & $6(1.4)$ & $2(1)$ & $4(1.8)$ & \\
\hline
\end{tabular}


TABLE E1. Continued

\begin{tabular}{|c|c|c|c|c|}
\hline Periprocedure data & $\begin{array}{c}\text { Total study } \\
\text { population }(N=436)\end{array}$ & Survivors $(\mathbf{n}=\mathbf{2 1 7})$ & Nonsurvivors $(\mathbf{n}=\mathbf{2 1 9})$ & $P$ value \\
\hline Other & $17(3.9)$ & $7(3.2)$ & $10(4.6)$ & \\
\hline CPB (min) & $242(175.3-321.8)$ & $221.5(165.5-313)$ & $256(185.3-322)$ & $.0398 *$ \\
\hline Xclamp (min) & $102(71.3-154)$ & $97(68-139)$ & $117(75-167)$ & $.0057^{*}$ \\
\hline CPR before implant & $92(21.1)$ & $42(19.4)$ & $50(22.8)$ & .4120 \\
\hline Implant during ongoing $\mathrm{CPR}$ & $25(5.7)$ & $13(6)$ & $12(5.5)$ & .8398 \\
\hline IABP & $37(8.5)$ & $16(7.4)$ & $21(9.6)$ & .4925 \\
\hline
\end{tabular}

Values are presented as median (interquartile range) for continuous variables and absolute numbers (\%) for categorical variables. EuroSCORE, European System for Cardiac Operative Risk Evaluation score; BMI, body mass index; $A S A T$, aspartate amino transferase; $A L A T$, alanine amino transferase; gamma-GT, gamma-glutamyl transferase; TIA, transient ischemic attack; $E C M O$, extracorporeal membrane oxygenation; $C P B$, cardiopulmonary bypass time; $C P R$, cardiopulmonary resuscitation; $C A B G$, coronary artery bypass graft; HTX, heart transplantation; Xclamp, aortic crossclamp time; IABP, intra-aortic balloon pump. *Significantly different.

TABLE E2. Cox proportional hazards model for mortality in patients undergoing postcardiotomy extracorporeal life support (PC-ECLS) $(\mathbf{N}=\mathbf{4 3 6})$

\begin{tabular}{lcc}
\hline \multicolumn{1}{c}{ Characteristic } & Hazard ratio (95\% CI) & \multicolumn{1}{c}{$\boldsymbol{P}$ value } \\
\hline Age & $1.011(1-1.02)$ & $.044^{*}$ \\
Male gender & $0.935(0.73-1.2)$ & .601 \\
Total bilirubin & $1.011(0.99-1.02)$ & .072 \\
Estimated glomerular filtration rate & $0.993(0.98-0.99)$ & $.006^{*}$ \\
Hemoglobin & $0.964(0.91-1.02)$ & .211 \\
Aortic crossclamp time & $1.001(1-1.01)$ & .156 \\
Duration of ECLS support & $1.04(1.01-1.07)$ & $.006^{*}$ \\
$\quad$ Initial arterial cannulation site & $1.12(0.87-1.44)$ & .369 \\
Procedure $\dagger$ & & $.015^{*}$ \\
$\quad$ Valve repair/replacement & $1.265(0.83-1.93)$ & .275 \\
Combined CABG/valve surgery & $1.3(0.85-2)$ & .231 \\
Aortic aneurysm surgery & $1.176(0.53-2.6)$ & .688 \\
Aortic dissection & $1.006(0.49-2.1)$ & .988 \\
HTX & $0.612(0.38-0.99)$ & $.048^{*}$ \\
Congenital heart disease & $2.09(0.77-5.6)$ & .148 \\
Other & $1.41(0.71-2.8)$ & .326 \\
\hline
\end{tabular}

$\overline{C I}$, Confidence interval; ECLS, extracorporeal life support; $C A B G$, coronary artery bypass graft; $H T X$, heart transplantation. *Significantly different. $\nmid$ Reference $=$ isolated CABG. 
TABLE E3. Distal perfusion cannula (DPC) utilization and complications related to extremity ischemia in patients with femoral arterial extracorporeal life support (ECLS) cannulation

\begin{tabular}{|c|c|c|c|c|}
\hline Complication & All patients $(\mathrm{N}=186)$ & DPC at implant $(n=121)$ & No or delayed DPC $(n=65)$ & $P$ value \\
\hline Leg ischemia & $31(16.7)$ & $17(14)$ & $14(21.5)$ & .2181 \\
\hline Compartment syndrome & $14(7.5)$ & $7(5.8)$ & $7(10.8)$ & .2500 \\
\hline Fasciotomy & $13(7)$ & $6(5)$ & $7(11)$ & .2256 \\
\hline Amputation & $3(1.6)$ & $2(1.7)$ & $1(1.5)$ & $>.9999$ \\
\hline $\begin{array}{l}\text { Cannulation site change due } \\
\text { to leg ischemia }\end{array}$ & $7(3.8)$ & $2(1.7)$ & $5(7.7)$ & .0518 \\
\hline
\end{tabular}

Values are presented as absolute numbers (\%). DPC, Distal perfusion cannula.

TABLE E4. Origin/pathomechanism and resulting morbidity of extremity ischemia in patients with axillary arterial cannulation and limb ischemia $(\mathbf{n}=12)$

\begin{tabular}{|c|c|c|c|}
\hline Patient & Affected limb & Likely origin/pathomechanism & Morbidity \\
\hline 1 & Left leg & $\begin{array}{l}\text { Prior left femoral arterial implant attempted, } \\
\text { venous cannula in left femoral vein, known } \\
\text { peripheral arterial disease }\end{array}$ & Fasciotomy of left thigh and lower leg \\
\hline 2 & Right arm & $\begin{array}{l}\text { Severe bleeding and hematoma formation at } \\
\text { axillary cannulation site }\end{array}$ & Fasciotomy of right arm \\
\hline 3 & Right leg & $\begin{array}{l}\text { Occurred after change of cannulation site to right } \\
\text { femoral }\end{array}$ & None \\
\hline 4 & Right arm & $\begin{array}{l}\text { Hyperperfusion and severe bleeding and } \\
\text { hematoma at axillary arterial cannulation site }\end{array}$ & Compartment syndrome \\
\hline 5 & Right arm & $\begin{array}{l}\text { Thrombotic occlusion of right subclavian and } \\
\text { brachial artery }\end{array}$ & $\begin{array}{l}\text { Thrombectomy of right upper extremity and } \\
\text { change of cannulation site to the left axillary } \\
\text { artery, amputation }\end{array}$ \\
\hline 6 & Left leg & Known left atrial thrombus, cardioembolism & $\begin{array}{l}\text { Fasciotomy and amputation of left leg, patient } \\
\text { also had an ischemic stroke (MRS 2) }\end{array}$ \\
\hline 7 & Right arm & $\begin{array}{l}\text { Severe bleeding and hematoma formation at } \\
\text { axillary cannulation site }\end{array}$ & $\begin{array}{l}\text { Fasciotomy and change of cannulation site to left } \\
\text { axillary artery }\end{array}$ \\
\hline 8 & Right arm & $\begin{array}{l}\text { Severe bleeding and hematoma formation at } \\
\text { axillary cannulation site }\end{array}$ & $\begin{array}{l}\text { Fasciotomy of right arm, change of cannulation } \\
\text { site to right femoral artery }\end{array}$ \\
\hline 9 & Right arm & $\begin{array}{l}\text { Hematoma formation and malperfusion, after } \\
\text { revision hyperperfusion }\end{array}$ & Fasciotomy of right arm \\
\hline 10 & Right arm & Unknown & Fasciotomy of right arm \\
\hline 11 & Right arm & $\begin{array}{l}\text { Thromboembolic occlusion of right ulnar and } \\
\text { radial artery, prior thrombus in arterial line } \\
\text { described }\end{array}$ & Ischemia of right hand \\
\hline 12 & Right leg & $\begin{array}{l}\text { Popliteal artery occlusion, venous cannula in } \\
\text { right femoral vein }\end{array}$ & Fasciotomy right lower leg \\
\hline
\end{tabular}

MRS, Modified ranking scale. 
TABLE E5. Baseline and periprocedural data of patients with $(n=32)$ and without $(n=404)$ fatal/disabling stroke

\begin{tabular}{|c|c|c|c|c|}
\hline Patient data & $\begin{array}{l}\text { Total study population } \\
\qquad(\mathrm{N}=\mathbf{4 3 6})\end{array}$ & $\begin{array}{c}\text { No fatal/disabling } \\
\text { stroke }(n=404)\end{array}$ & $\begin{array}{l}\text { Fatal/disabling } \\
\text { stroke }(n=32)\end{array}$ & $P$ value \\
\hline Age (y) & $67.0(57.2-73.8)$ & $67.2(57.1-74)$ & $67(60.1-74.5)$ & .6737 \\
\hline Male & $287(65.8)$ & $268(66.3)$ & $19(59.4)$ & .4423 \\
\hline EuroSCORE II & $14.2(5.9-30.9)$ & $14.1(5.9-31.6)$ & $14.2(5.5 .-21.7)$ & .7362 \\
\hline BMI & $26.8(24.0-30.0)$ & $26.7(24.1-30)$ & $28.2(23.1-30)$ & .8798 \\
\hline Hypertension & $312(71.6)$ & $288(71.3)$ & $24(75)$ & .8389 \\
\hline Hypercholesterolemia & $236(54.1)$ & $215(53.2)$ & $21(65.6)$ & .1999 \\
\hline $\begin{array}{l}\text { Insulin-dependent diabetes } \\
\text { mellitus }\end{array}$ & $32(7.3)$ & $29(7.2)$ & $3(9.4)$ & .7202 \\
\hline Coronary artery disease & $243(55.7)$ & $229(56.7)$ & $14(43.8)$ & .1956 \\
\hline Creatinine (mg/dL) & $1.3(1-1.8)$ & $1.3(1-1.8)$ & $1.1(0.9-1.6)$ & .0584 \\
\hline $\begin{array}{l}\text { Estimated glomerular } \\
\text { filtration rate }(\mathrm{mL} / \mathrm{min} / \\
\left.1,73 \mathrm{~m}^{2}\right)\end{array}$ & $57.4(39.4-79)$ & $56.8(39.3-77.7)$ & $66.6(41.2-90.7)$ & .2292 \\
\hline Blood urea nitrogen $(\mathrm{mg} / \mathrm{dL})$ & $24(17-36.8)$ & $24(17.4-37)$ & $21.9(14.8-29.6)$ & .1587 \\
\hline Total bilirubin (mg/dL) & $1(0.6-1.2)$ & $1(0.6-1.2)$ & $1(0.4-1.4)$ & .9089 \\
\hline ASAT (U/L) & $30(22-52.3)$ & $30(22-53)$ & $29(22.8-43.8)$ & .6225 \\
\hline ALAT (U/L) & $26(18-43)$ & $26(17.8-43)$ & $33(20-44.5)$ & .3760 \\
\hline Gamma-GT (U/L) & $59(33-104)$ & $59(33-106.5)$ & $54.5(35.8-89.3)$ & .7018 \\
\hline Hemoglobin (mg/dL) & $12(10.3-13.9)$ & $12(10.3-14)$ & $12(10.5-13)$ & .3362 \\
\hline C-reactive protein $(\mathrm{mg} / \mathrm{dL})$ & $1(0.1-4)$ & $1(0.2-4)$ & $0.9(0.1-2.1)$ & .5026 \\
\hline Peripheral arterial disease & $61(14)$ & 55 (13.6) & $6(18.8)$ & .4265 \\
\hline Cerebrovascular disease & $62(14.2)$ & $59(14.6)$ & $3(9.4)$ & .5995 \\
\hline Previous stroke/TIA & $74(17)$ & 67 (16.6) & 7 (21.9) & .4626 \\
\hline Previous cardiac surgery & 139 (31.9) & $128(31.7)$ & $11(34.4)$ & .8440 \\
\hline Active endocarditis & $46(10.6)$ & 43 (10.6) & $3(9.4)$ & $>.9999$ \\
\hline \multicolumn{5}{|l|}{ ECMO indication } \\
\hline $\begin{array}{l}\text { CPB weaning failure } \\
\text { (implanted during initial } \\
\text { surgery) }\end{array}$ & $321(73.6)$ & $297(73.5)$ & $24(75)$ & $>.9999$ \\
\hline $\begin{array}{l}\text { Hemodynamic decline/ } \\
\text { CPR/respiratory failure } \\
\text { after cardiac surgery } \\
\text { (implanted within } 72 \mathrm{~h} \\
\text { after end of surgery) }\end{array}$ & $115(26.4)$ & $107(26.5)$ & $8(25)$ & $>.9999$ \\
\hline Duration of support (d) & $4.31(2.71-6.7)$ & $4.22(2.68-6.67)$ & $5.1(3.6-10.2)$ & $.0336^{*}$ \\
\hline $\begin{array}{l}\text { Initial cannulation } \\
\text { site = axillary }\end{array}$ & $250(57.3)$ & $222(55)$ & $28(87.5)$ & $.0003^{*}$ \\
\hline \multicolumn{5}{|l|}{ Procedure details } \\
\hline Isolated CABG & $51(11.7)$ & $50(12.4)$ & $1(3.1)$ & .1547 \\
\hline Valve repair/replacement & $131(30)$ & $118(29.2)$ & $13(40.6)$ & .2281 \\
\hline $\begin{array}{l}\text { Combined CABG/valve } \\
\text { surgery }\end{array}$ & $113(25.9)$ & $104(25.7)$ & $9(28.1)$ & .8341 \\
\hline Aortic surgery & $37(8.5)$ & $31(7.7)$ & $6(18.8)$ & $.0431 *$ \\
\hline Type A aortic dissection & $24(5.5)$ & $22(5.4)$ & $2(6.25)$ & \\
\hline
\end{tabular}


TABLE E5. Continued

\begin{tabular}{|c|c|c|c|c|}
\hline Patient data & $\begin{array}{c}\text { Total study population } \\
(\mathbf{N}=\mathbf{4 3 6})\end{array}$ & $\begin{array}{c}\text { No fatal/disabling } \\
\text { stroke }(n=404)\end{array}$ & $\begin{array}{l}\text { Fatal/disabling } \\
\text { stroke }(\mathbf{n}=32)\end{array}$ & $P$ value \\
\hline Aortic aneurysm surgery & $13(3.2)$ & $9(2.2)$ & $4(12.5)$ & \\
\hline HTX & $81(18.6)$ & $79(19.6)$ & $2(7.1)$ & .0942 \\
\hline Congenital heart disease & $6(1.4)$ & $6(1.5)$ & $0(0)$ & $>.9999$ \\
\hline Other & $17(3.9)$ & $16(4)$ & $1(3.1)$ & $>.9999$ \\
\hline $\mathrm{CPB}(\min )$ & $242(175.3-321.8)$ & $242(175.3-316)$ & $270(174.5-338.3)$ & .4299 \\
\hline Xclamp (min) & $102(71.3-154)$ & $101(70-153)$ & $133(96.5-200.5)$ & $.0044 *$ \\
\hline CPR before implant & $92(21.1)$ & $82(20.3)$ & $10(31.25)$ & .1746 \\
\hline Implant during ongoing CPR & $25(5.7)$ & $24(5.9)$ & $1(3.1)$ & $>.9999$ \\
\hline IABP & $37(8.5)$ & $37(9.2)$ & $0(0)$ & .0955 \\
\hline
\end{tabular}

Values are presented as median (interquartile range) for continuous variables and absolute numbers (\%) for categorical variables. EuroSCORE, European System for Cardiac Operative Risk Evaluation score; $B M I$, body mass index; $A S A T$, aspartate amino transferase; $A L A T$, alanine amino transferase; gamma-GT, gamma-glutamyl transferase; TIA, transient ischemic attack; $E C M O$, extracorporeal membrane oxygenation; $C P B$, cardiopulmonary bypass time; $C P R$, cardiopulmonary resuscitation; $C A B G$, coronary artery bypass graft; HTX, heart transplantation; Xclamp, aortic crossclamp time; IABP, intra-aortic balloon pump. *Significant difference.

TABLE E6. Characterization of all strokes $(\mathrm{N}=48)$ with timing and clinical indication for cerebral computed tomography $(C C T)$, preceding extracorporeal life support (ECLS)-related events, and possible causes

\begin{tabular}{|c|c|c|c|c|c|c|}
\hline $\begin{array}{l}\text { Cannulation } \\
\text { site group }\end{array}$ & Patient & Timing of CCT & Indication for CCT & $\begin{array}{l}\text { Hemorrhagic/ } \\
\text { ischemic }\end{array}$ & $\begin{array}{l}\text { MRS at } \\
\text { discharge }\end{array}$ & Likely cause of stroke \\
\hline \multirow[t]{13}{*}{ Axillary artery } & 1 & $\begin{array}{l}\text { Respiratory weaning/ } \\
\text { after explant }\end{array}$ & Reduced vigilance & Hemorrhagic & 1 & Unknown \\
\hline & 2 & $\begin{array}{l}\text { Respiratory weaning/ } \\
\text { after explant }\end{array}$ & Left-sided hemiplegia & Ischemic & 4 & ECLS \\
\hline & 3 & $\begin{array}{l}\text { Respiratory weaning/ } \\
\text { after explant }\end{array}$ & Left-sided hemiparesis & Ischemic & 4 & ECLS \\
\hline & 4 & $\begin{array}{l}\text { Respiratory weaning/ } \\
\text { after explant }\end{array}$ & Coma & Hemorrhagic & 6 & ECLS \\
\hline & 5 & Directly after explant & $\begin{array}{l}\text { Sudden onset fixed dilated } \\
\text { pupils }\end{array}$ & Hemorrhagic & 6 & ECLS explant \\
\hline & 6 & $2 \mathrm{~d}$ after explant & $\begin{array}{l}\text { Left-sided hemiplegia, } \\
\text { decrease of right-sided } \\
\text { near-infrared spectroscopy } \\
\text { to } 29 \% \text { directly after ECLS } \\
\text { explant }\end{array}$ & Ischemic & 4 & ECLS explant \\
\hline & 7 & $\begin{array}{l}\text { Respiratory weaning/ } \\
\text { after explant }\end{array}$ & Reduced vigilance & Ischemic & 2 & ECLS \\
\hline & 8 & $\begin{array}{l}\text { Respiratory weaning/ } \\
\text { after explant }\end{array}$ & Coma & Ischemic & 4 & ECLS \\
\hline & 9 & After extubation & Paresis of right arm & Ischemic & 2 & $\begin{array}{l}\text { ECLS or surgery related (type } \\
\text { a aortic dissection) }\end{array}$ \\
\hline & 10 & $\begin{array}{l}2 \text { wk after ECLS } \\
\text { explant, on regular } \\
\text { ward before } \\
\text { discharge }\end{array}$ & Visual field loss & Ischemic & 1 & $\begin{array}{l}\text { Unknown/patient also had } \\
\text { type a dissection }\end{array}$ \\
\hline & 11 & $\begin{array}{l}\text { During ECLS run (day } \\
\text { 6) }\end{array}$ & $\begin{array}{l}\text { Sudden onset fixed dilated } \\
\text { pupils on day } 6 \text { during } \\
\text { ECLS run }\end{array}$ & Hemorrhagic & 6 & ECLS \\
\hline & 12 & $\begin{array}{l}\text { Respiratory weaning/ } \\
\text { after explant }\end{array}$ & Reduced vigilance & Ischemic & 1 & $\begin{array}{l}\text { Unknown, patient also } \\
\text { underwent perioperative } \\
\text { CPR }\end{array}$ \\
\hline & 13 & & Left-sided hemiplegia & Ischemic & 4 & \\
\hline
\end{tabular}

(Continued) 
TABLE E6. Continued

\begin{tabular}{|c|c|c|c|c|c|c|}
\hline \multirow{2}{*}{\multicolumn{2}{|c|}{$\begin{array}{c}\text { Cannulation } \\
\text { site group }\end{array}$}} & Timing of CCT & Indication for CCT & $\begin{array}{l}\text { Hemorrhagic/ } \\
\text { ischemic }\end{array}$ & $\begin{array}{c}\text { MRS at } \\
\text { discharge }\end{array}$ & Likely cause of stroke \\
\hline & & $\begin{array}{l}\text { Respiratory weaning/ } \\
\text { after explant }\end{array}$ & & & & $\begin{array}{l}\text { Patient also had mechanical } \\
\text { mitral valve thrombosis }\end{array}$ \\
\hline & 14 & $\begin{array}{l}\text { During ECLS run (day } \\
\text { 3) }\end{array}$ & $\begin{array}{l}\text { Sudden onset anisocoria at } \\
\text { day } 3 \text { of ECLS }\end{array}$ & Ischemic & 6 & ECLS \\
\hline & 15 & $\begin{array}{l}\text { Respiratory weaning/ } \\
\text { after explant }\end{array}$ & $\begin{array}{l}\text { Coma, leftsided hemiplegia, } \\
\text { embolectomy of right } \\
\text { brachial artery after ECLS } \\
\text { explant }\end{array}$ & ischemic & 6 & $\begin{array}{l}\text { ECLS related: CCT at } \\
\text { beginning of ECLS normal, } \\
\text { embolectomy right brachial } \\
\text { artery after explant }\end{array}$ \\
\hline & 16 & $\begin{array}{l}\text { Respiratory weaning/ } \\
\text { after explant }\end{array}$ & Tetraparesis & Ischemic & 5 & ECLS \\
\hline & 17 & $\begin{array}{l}\text { Respiratory weaning/ } \\
\text { after explant }\end{array}$ & Tetraplegia and coma & Ischemic & 6 & $\begin{array}{l}\text { Known left atrial thrombus } \\
\text { and systemic embolism, } \\
\text { also to left leg }\end{array}$ \\
\hline & 18 & $\begin{array}{l}\text { Respiratory weaning/ } \\
\text { after explant }\end{array}$ & Unknown & Ischemic & 3 & Unknown \\
\hline & 19 & $\begin{array}{l}\text { Before hospital } \\
\text { discharge }\end{array}$ & Visual field loss & Ischemic & 1 & $\begin{array}{l}\text { Unknown, patient underwent } \\
\text { concomitant right-sided } \\
\text { carotid endarterectomy }\end{array}$ \\
\hline & 20 & $\begin{array}{l}\text { During ECLS run } \\
\quad(\text { day } 3)\end{array}$ & $\begin{array}{r}\text { Sudden onset fixed dilated } \\
\text { pupils at day } 3 \text { of ECLS }\end{array}$ & Hemorrhagic & 6 & On ECLS \\
\hline & 21 & $\begin{array}{l}\text { Respiratory weaning/ } \\
\text { after explant }\end{array}$ & Hemiplegia & Ischemic & 4 & ECLS \\
\hline & 22 & $\begin{array}{l}\text { During ECLS run (day } \\
\text { 4) }\end{array}$ & $\begin{array}{l}\text { Sudden onset anisocoria on } \\
\text { day } 4 \text { of ECLS }\end{array}$ & Hemorrhagic & 6 & On ECLS \\
\hline & 23 & $\begin{array}{l}\text { Respiratory weaning/ } \\
\text { after explant }\end{array}$ & NCSE & Ischemic & 5 & $\begin{array}{l}\text { Unknown, also underwent } \\
\text { CPR }\end{array}$ \\
\hline & 24 & $\begin{array}{l}\text { Respiratory weaning/ } \\
\text { after explant }\end{array}$ & $\begin{array}{l}\text { Aphasia, leftsided } \\
\text { Hemiparesis }\end{array}$ & Ischemic & 3 & $\begin{array}{c}\text { ECLS explanted because of } \\
\text { device thrombosis despite } \\
\text { adequate anticoagulation }\end{array}$ \\
\hline & 25 & $\begin{array}{l}\text { Respiratory weaning/ } \\
\text { after explant }\end{array}$ & Hemiplegia & Ischemic & 4 & $\begin{array}{l}\text { ECLS, arterial cannula was } \\
\text { changed due to thrombus } \\
\text { formation }\end{array}$ \\
\hline & 26 & During ECLS run & Seizure & Ischemic & 2 & ECLS \\
\hline & 27 & $\begin{array}{l}\text { Respiratory weaning/ } \\
\text { after explant }\end{array}$ & Reduced vigilance & Ischemic & 1 & Unknown \\
\hline & 28 & $\begin{array}{l}\text { Respiratory weaning/ } \\
\text { after explant }\end{array}$ & $\begin{array}{l}\text { Left-sided hemiplegia and } \\
\text { dysphagia }\end{array}$ & Ischemic & 4 & $\begin{array}{l}\text { Patient had normal CCT } 2 \mathrm{~d} \\
\text { before ECLS explant, large } \\
\text { right sided ischemic stroke } \\
\text { in CCT } 3 \mathrm{~d} \text { after ECLS } \\
\text { explant }\end{array}$ \\
\hline & 29 & $\begin{array}{l}\text { After arterial cannula } \\
\text { change (same day) }\end{array}$ & $\begin{array}{l}\text { Sudden onset anisocoria after } \\
\text { cannula exchange }\end{array}$ & Hemorrhagic & 6 & $\begin{array}{l}\text { Normal CCT } 2 \text { d prior to } \\
\text { explant, onset of anisocoria } \\
\text { after arterial cannula } \\
\text { change due to thrombus } \\
\text { formation }\end{array}$ \\
\hline & 30 & $\begin{array}{l}\text { Respiratory weaning/ } \\
\text { after explant }\end{array}$ & Myoclonia & Ischemic & 5 & $\begin{array}{l}\text { Unknown, potentially ECLS } \\
\text { related }\end{array}$ \\
\hline & 31 & $\begin{array}{l}\text { Respiratory weaning/ } \\
\text { after explant }\end{array}$ & $\begin{array}{l}\text { Reduced vigilance, positive } \\
\text { Babinski right side }\end{array}$ & Ischemic & 4 & ECLS \\
\hline & 32 & Directly after explant & $\begin{array}{l}\text { fixed dilated pupils after } \\
\text { explant, thrombus in } \\
\text { arterial cannula }\end{array}$ & Ischemic & 6 & $\begin{array}{l}2 \mathrm{~d} \text { after explant, occlusion of } \\
\text { the right internal carotid } \\
\text { artery was diagnosed and } \\
\text { patient underwent } \\
\text { thrombectomy; however, }\end{array}$ \\
\hline
\end{tabular}


TABLE E6. Continued

\begin{tabular}{|c|c|c|c|c|c|c|}
\hline $\begin{array}{l}\text { Cannulation } \\
\text { site group }\end{array}$ & Patient & Timing of CCT & Indication for CCT & $\begin{array}{l}\text { Hemorrhagic/ } \\
\text { ischemic }\end{array}$ & $\begin{array}{l}\text { MRS at } \\
\text { discharge }\end{array}$ & Likely cause of stroke \\
\hline & & & & & & $\begin{array}{l}\text { patient developed a fatal } \\
\text { stroke. Thrombotic } \\
\text { material in the arterial } \\
\text { cannula was noted at the } \\
\text { time of explant }\end{array}$ \\
\hline & 33 & On ECLS (day 3) & $\begin{array}{l}\text { Sudden onset fixed dilated } \\
\text { pupils }\end{array}$ & Hemorrhagic & 6 & ECLS \\
\hline & 34 & $\begin{array}{l}\text { Respiratory weaning/ } \\
\text { after explant }\end{array}$ & Coma & Ischemic & 6 & Unknown, $30 \mathrm{~min}$ CPR \\
\hline & 35 & During ECLS (day 5) & Seizure & Ischemic & 1 & ECLS \\
\hline & 36 & $\begin{array}{l}\text { On ECLS (day 3), } \\
\text { after revision for } \\
\text { mediastinal } \\
\text { bleeding }\end{array}$ & $\begin{array}{l}\text { Sudden onset fixed dilated } \\
\text { pupils }\end{array}$ & Hemorrhagic & 6 & $\begin{array}{l}\text { Hypertensive phase during } \\
\text { revision for bleeding; fixed } \\
\text { unresponsive pupils after } \\
\text { revision } \rightarrow \text { CCT }\end{array}$ \\
\hline & 37 & $\begin{array}{l}\text { Respiratory weaning/ } \\
\text { after explant }\end{array}$ & Reduced vigilance and seizure & Ischemic & 3 & Unknown \\
\hline & 38 & $\begin{array}{l}\text { During ECLS run (day } \\
\text { 24) }\end{array}$ & Unknown & Ischemic & 6 & ECLS \\
\hline & 39 & $\begin{array}{l}\text { Respiratory weaning/ } \\
\text { after explant }\end{array}$ & $\begin{array}{l}\text { Hemiparesis and aphasia after } \\
\text { extubation }\end{array}$ & Ischemic & 4 & ECLS \\
\hline & 40 & During ECLS (day 17) & Seizures, dilated pupils & Hemorrhagic & 6 & ECLS \\
\hline & 41 & $\begin{array}{l}\text { Respiratory weaning/ } \\
\text { after explant }\end{array}$ & Unknown & Ischemic & 1 & $\begin{array}{l}\text { Unknown, also had aortic } \\
\text { dissection }\end{array}$ \\
\hline \multirow[t]{7}{*}{ Femoral artery } & 1 & $\begin{array}{l}\text { Respiratory weaning/ } \\
\text { after explant }\end{array}$ & Reduced vigilance & Ischemic & 1 & ECLS \\
\hline & 2 & $\begin{array}{l}\text { Respiratory weaning/ } \\
\text { after explant }\end{array}$ & Reduced vigilance & Ischemic & 4 & $\begin{array}{l}\text { Embolic? Patient also } \\
\text { underwent CPR before } \\
\text { implant }\end{array}$ \\
\hline & 3 & $\begin{array}{l}\text { Respiratory weaning/ } \\
\text { after explant }\end{array}$ & Unknown & Ischemic & 1 & $\begin{array}{l}\text { Watershed infarct, CPR } \\
\text { before implant }\end{array}$ \\
\hline & 4 & $\begin{array}{l}\text { During ECLS run (day } \\
\quad 6)\end{array}$ & Anisocoria & Ischemic & 6 & $\begin{array}{l}\text { On ECLS, cannulation site } \\
\text { was changed from femoral } \\
\text { to axillary artery } 4 \mathrm{~d} \text { before } \\
\text { the event }\end{array}$ \\
\hline & 5 & $\begin{array}{l}\text { Respiratory weaning/ } \\
\text { after explant }\end{array}$ & Hemiparesis & Ischemic & 3 & Unknown, perioperative CPR \\
\hline & 6 & On ECLS (day 8) & Anisocoria during ECLS run & Ischemic & 6 & $\begin{array}{l}\text { ECLS, Cannulation site was } \\
\text { changed from femoral to } \\
\text { axillary artery on day } 4 \\
\text { after implant }\end{array}$ \\
\hline & 7 & On ECLS (day 7) & $\begin{array}{l}\text { Evaluation for durable left } \\
\text { ventricular assist device } \\
\text { implantation }\end{array}$ & Ischemic & 6 & $\begin{array}{l}\text { Mechanical mitral valve } \\
\text { thrombosis }\end{array}$ \\
\hline
\end{tabular}

$\overline{C C T \text {, Cerebral computed tomography; } M R S \text {, modified ranking scale; } E C L S \text {, extracorporeal life support; } C P R \text {, cardiopulmonary resuscitation; NCSE, nonconvulsive status }}$ epilepticus. 